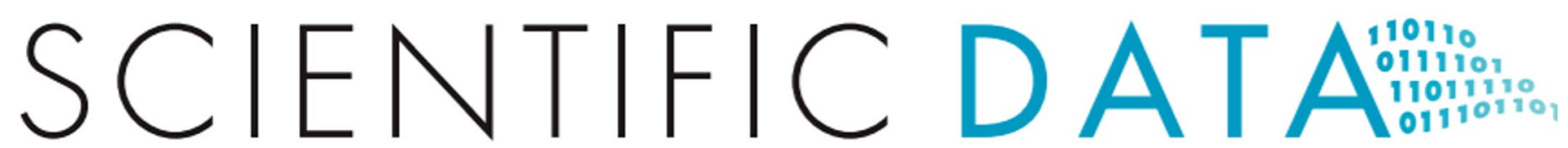

Check for updates

OPEN

DATA DESCRIPTOR

\section{A global dataset for crop production under conventional tillage and no tillage systems}

Yang Su ${ }^{1 \otimes}$, Benoit Gabrielle ${ }^{1}{ }^{1}$ \& David Makowski ${ }^{2,3}$

No tillage (NT) is often presented as a means to grow crops with positive environmental externalities, such as enhanced carbon sequestration, improved soil quality, reduced soil erosion, and increased biodiversity. However, whether NT systems are as productive as those relying on conventional tillage (CT) is a controversial issue, fraught by a high variability over time and space. Here, we expand existing datasets to include the results of the most recent field experiments, and we produce a global dataset comparing the crop yields obtained under CT and NT systems. In addition to crop yield, our dataset also reports information on crop growing season, management practices, soil characteristics and key climate parameters throughout the experimental year. The final dataset contains 4403 paired yield observations between 1980 and 2017 for eight major staple crops in 50 countries. This dataset can help to gain insight into the main drivers explaining the variability of the productivity of NT and the consequence of its adoption on crop yields.

\section{Background \& Summary}

Often featured among promising climate change mitigation measures, NT systems, including conservation agriculture (CA), contribute to environmental preservation and sustainable agricultural production ${ }^{1,2}$. NT is expected to mitigate soil degradation, improve soil structure and water retention properties ${ }^{3-5}$. Several studies indicate that this cropping system can provide a large range of positive environmental externalities such as increased biodiversity, enhanced carbon sequestration and improved soil quality through an increase in soil organic matter ${ }^{6-10}$. However, the productivity of NT systems compared to conventional cropping systems is still controversial. Since the productivity of NT depends on several interacting factors such as climatic conditions ${ }^{11}$, soil characteristics ${ }^{1,12}$, and other agricultural management activities ${ }^{13-19}$, the potential of NT to increase agricultural productivity remains highly uncertain.

Several studies ${ }^{1,12,20-22}$ have been conducted to synthetize the current evidence on the productivity in NT systems. Some of these studies relied on global datasets including results of field experiments comparing NT and CT cropping systems over a large range of soil and climate conditions. However, these datasets do not include the most recent published experiments, and provide no or limited information on soil characteristics, climate variables, and management practices. In particular, information on fertilizer inputs, weed and pest control, and intraand inter- annual climatic variability are frequently missing. Other studies comparing NT and CT rely on a limited number of experiments, are only conducted at a regional scale, or did not make their data fully available ${ }^{23-25}$. Thus, a global dataset reporting findings from the most recent field experiments and including information about a wide range of climatic parameters, soil characteristics and agricultural management practices is still lacking.

To address this gap, we present an updated and extended dataset comparing CT and NT productivity including the most recently published experimental studies, and a detailed description of their environmental characteristics and management practices. Our dataset contains 4403 paired (NT vs. CT) yield observations collected between 1980 and 2017 for eight major staple crops in 50 countries. For each experiment, we provide information on soil texture, $\mathrm{pH}$, the year and month of crop planting and harvesting, the location of the experiment, fertilization, weed and pest control practices, crop type, crop rotation, crop residue management, and crop irrigation. Besides soil characteristics and information on management practices, we also report a large range of climate variables derived from several external databases. These include precipitation, potential evapotranspiration, average

${ }^{1}$ UMR ECOSYS, INRAE AgroParisTech, Université Paris-Saclay, 78850, Thiverval-Grignon, France. ${ }^{2}$ UMR Agronomie, INRAE AgroParisTech, Université Paris-Saclay, 78850, Thiverval-Grignon, France. ${ }^{3}$ Applied mathematics and computer science (MIA 518), INRAE AgroParisTech, Université Paris-Saclay, 75005, Paris, France. ${ }^{\bowtie e-m a i l: ~ y a n g . s u @ i n r a e . f r ~}$ 


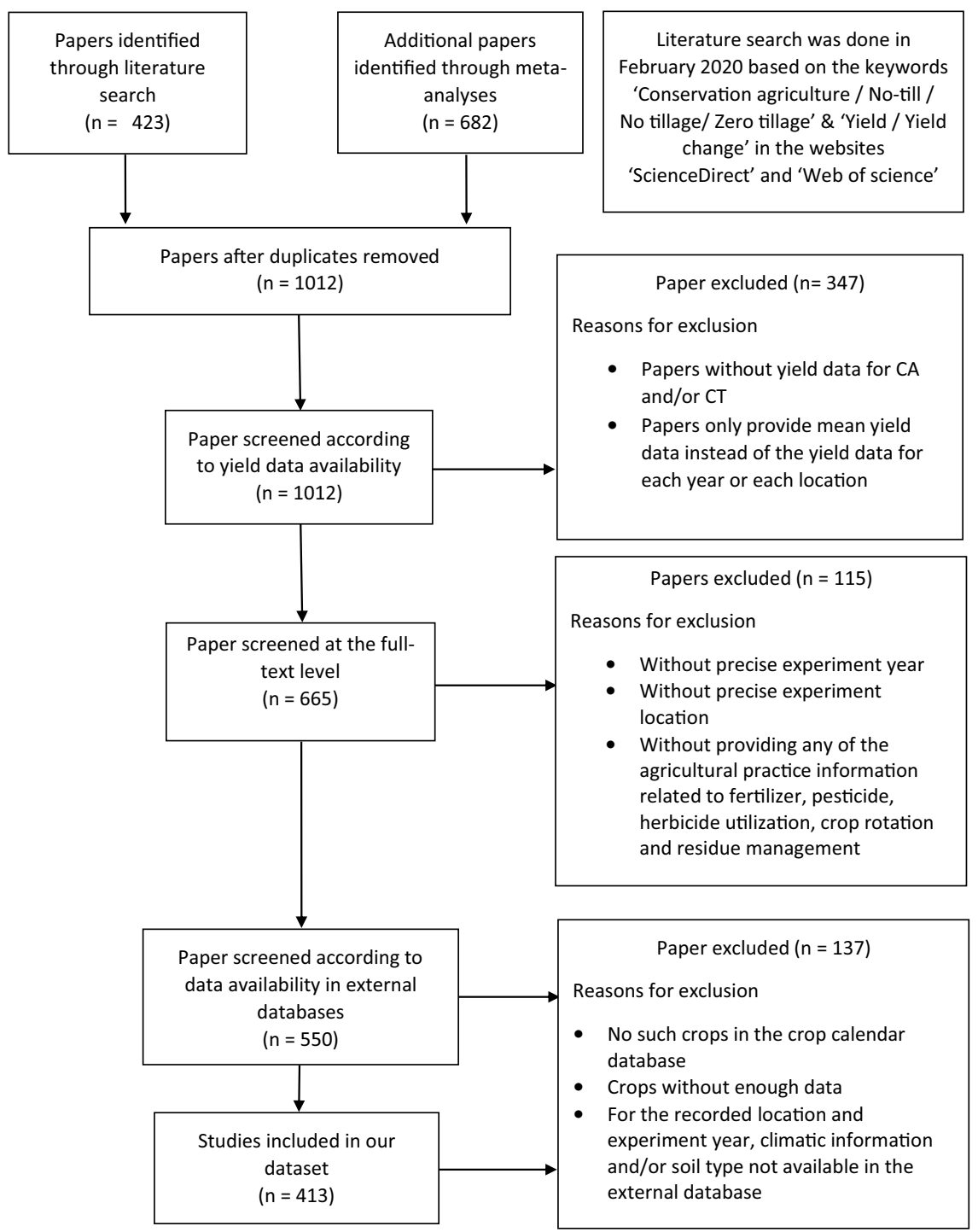

Fig. 1 Flow chart of paper collection and selection.

temperature, maximum temperature, and minimum temperature during the crop growing season. This dataset can prove useful to disentangle the effects of soil, climate and agronomic drivers of crop yields when comparing NT with CT systems.

\section{Methods}

Data collection. The literature search was done in February 2020 using the following keywords 'Conservation agriculture/No-till/No tillage/Zero tillage' \& 'Yield/Yield change' in the websites 'ScienceDirect,' 'Science Citation Index (web of science)'. A total of 1012 potentially relevant papers were identified by reviewing the title and abstract, and these papers were then screened according to the procedure summarized in Fig. 1. Papers not reporting yield data for CT and NT systems were excluded, as well as papers reporting experiments on reduced tillage (RT) systems. Papers reporting only mean yield data across different years or sites were also excluded. We then checked whether information on fertilization, weed and pest control, crop irrigation, crop rotation and crop residue management were reported for both CT and NT practices. After these screening and selection steps, all relevant data were manually extracted from the selected papers, including general information about the paper, location and year of the experiment, the number of years under NT when the crop was sown, soil characteristics, crop growing season, crop type, crop management practices and crop yield of CT and NT. However, due to a large number of missing data, the crop growing season, climatic variables and soil characteristics were finally collected through several external databases (Online-only Table 1). The growing season information was generated from a crop calendar database ${ }^{26,27}$ based on the crop type and the locations of the experiments reported in the papers. The precipitation, average temperature in the growing season were extracted from the UDel_AirT_Precip data provided by NOAA/OAR/ESRL PSL ${ }^{28}$. The maximum and minimum air temperature during the growing season were generated from CPC Global Temperature data provided by NOAA/OAR/ESRL PSL ${ }^{29}$ and the potential evapotranspiration data over the growing season were extracted from GLEAM database $\mathrm{e}^{30,31}$. Soil textures were collected from the HWSD database ${ }^{32}$ using the locations of the experimental sites reported in the selected papers 


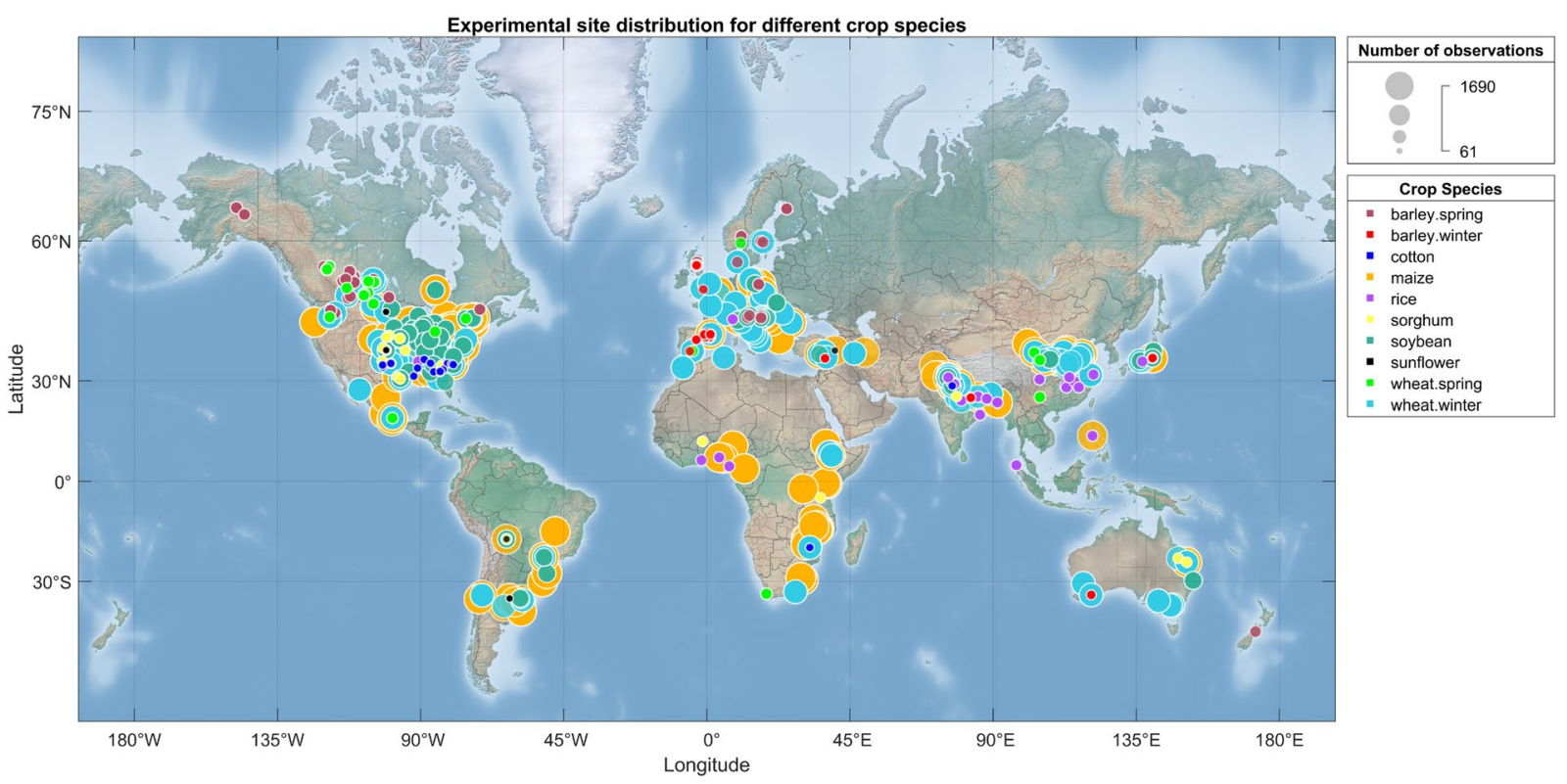

Fig. 2 Distribution of experimental sites. The size of the circle indicates the number of observations, and the colours indicates the crop species.

(see Online-only Table 1 for additional details). The experiments for which it was not possible to obtain the requested information from the external databases were excluded. The final dataset includes the results extracted from 413 papers (published between 1983 to 2020), 4403 paired yield observations from NT and CT for 8 major crop species, including 370 observations for barley (232 observations for spring barley and 138 for winter barley), 94 observations for cotton, 1690 observations for maize, 195 observation for rice, 160 observations for sorghum, 583 observations for soybean, 61 observations for sunflower, 1250 observations for wheat (1041 observations for winter wheat and 209 observations for spring wheat) in 50 countries from 1980 to 2017 (Fig. 2).

\section{Data Records}

All data are available on the figshare repository ${ }^{33}$, which can be accessed through the link: https://doi.org/10.6084/ m9.figshare.12155553. Four files are provided:

1. "Database.csv" includes the data.

2. "Summary of the database.docx", includes the summary of dataset which explains the definition or assumption for each column in the dataset.

3. "List of references.docx" reports the references of the studies from which data were extracted.

4. "Code.zip", includes all the codes used in this study.

Online-only Table 1 shows the metadata of our dataset. Six main categories of data are provided:

Category I covers authors, publishing journal and the publishing year.

Category II reports general information about the experiments, including country, location (villages or cities), latitude, longitude of experiment site, soil type and $\mathrm{pH}$ at experimental sites, number of replicates, crop types, the initial year of NT practice, crop planting/harvesting month/year, and the period since the initial year of NT practice.

Category III covers information about agricultural management activities under both NT and CT systems (data availabilities of those activities were shown in Fig. 3):

- Crop rotation with at least 3 crops involved (based on the crop rotation principle of CA defined by FAO ${ }^{34}$ ): "Yes", "No", "Not reported". The details of crop sequence are also provided.

- Soil cover: "Yes", "No", "Mixed", "Not reported". Details of residue management for the previous crops are also provided.

- Weed and pest control: "Yes", "No", "Mixed", "Not reported".

- Field fertilization: "Yes", "No", "Mixed", "Not reported". The details of N input and other fertilizer input are also provided.

- Crop irrigation: "Yes", "No", "Mixed", "Not reported". The details of the amount of water applied are also provided.

Category IV contains detailed information about the experiment site, experiment setting, management activities, depending on the papers, it may also include the type and quantity used of fertilizer, herbicide, or pesticide. 



Fig. 3 Data availability and break-down of the different crop management practices and NT implementation periods reported in the dataset.

Category V corresponds to data related to crop yield. It includes the paired crop yields under CT ( Yield $_{C T}$ ) and NT $\left(\right.$ Yield $\left._{N T}\right)$ systems. The relative yield changes is defined as $\frac{\text { Yield }_{N T}-\text { Yield }_{C T}}{\text { Yield }_{C T}}$. The column "Yield increase with NT" reports whether the differences between Yield $_{C T}$ and Yield ${ }_{N T}$ are positive or negative ("Yes" indicates that crop yield is increased with NT practice, while "No" indicates that yield is not increased).

Category VI includes data extracted from the external databases, including crop growing season, climate variables (including precipitation, potential evapotranspiration, minimum/average/maximum temperature) during the growing season, and soil texture.

Crop growing season is defined by a start month and end month, which were extracted from the external crop calendar databases ${ }^{26}$ of spring barley, winter barley, cotton, maize, rice, sorghum, soybean, sunflower, spring wheat and winter wheat based on the crop type and study sites. Data on the crop calendar corresponds to averaged data and does not change intra-annually, thus the growing season extracted may be different from the actual growing season.

The climatic variables from the external databases are:

- Accumulated precipitation (P) during the growing season (sum of monthly precipitations during the growing season),

- Accumulated potential evapotranspiration (E) (sum of monthly evapotranspiration rates during the growing season),

- Precipitation balance (PB), defined as $\mathrm{PB}=\mathrm{P}-\mathrm{E}^{12}$,

- Average air temperature (Tave) during the growing season,

- Maximum air temperature (Tmax): the maximum value among the daily temperatures in the growing season,

- Minimum air temperature (Tmin): the minimum value among the daily temperatures in the growing season.

Soil texture was extracted from an external database based ${ }^{32}$ on the experiments' locations. In total seven texture classes were included: sandy loam, loam, silt loam, sandy clay loam, clay loam, sandy clay and clay.

\section{Technical Validation}

To ensure the reliability of the information collected from the papers, we carefully checked and compared all the collected data with the original paper several times. Quality control of the database was conducted based on outlier detection. For each crop, the outliers of crop yield in CT system and NT system were identified based on the Interquartile Rule ${ }^{35}$ outlier detection method. For each crop species, an interquartile range (IQR) is defined as the difference between the first and third quartile of crop yield, and a threshold is calculated by adding 1.5 IQR to the third quartile. Any yield data beyond this threshold is flagged as an outlier for the crop species considered. The ratio of crop yield in NT and CT systems $\left(\frac{\text { Yield }_{N T}}{\text { Yield }_{C T}}\right)$ were also calculated. All outliers and all the observations with a ratio higher than 2 were checked and compared with the values reported in the original papers one more time.

The crop yield values reported in our dataset are consistent with results of previous published studies. Comparing crop yield data of NT and CT, the adoption of NT practice overall leads to a yield decrease (Fig. 4a). A similar trend of crop production decrease with NT was reported in previous studies ${ }^{1,12,20,36}$. We also find that the combination of NT with crop rotation and soil cover (known as CA) trends to increase crop yield compared to 
(a). Log yield ratio of NT/CT

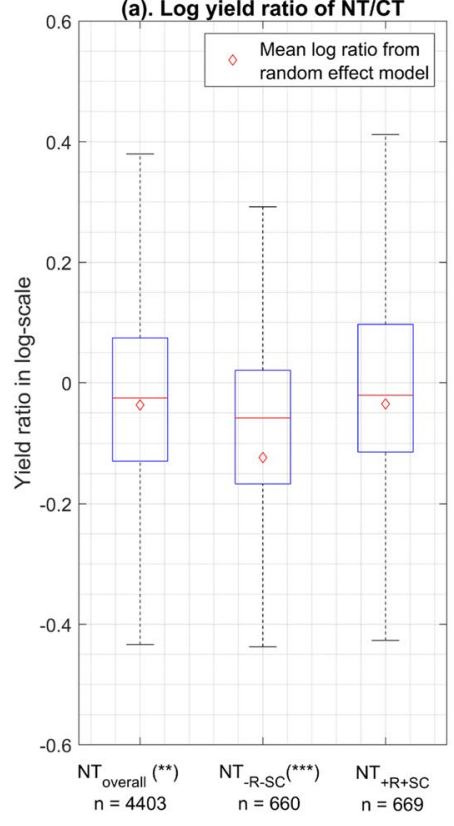

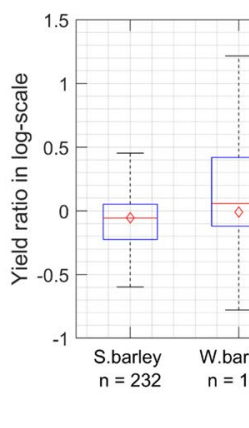

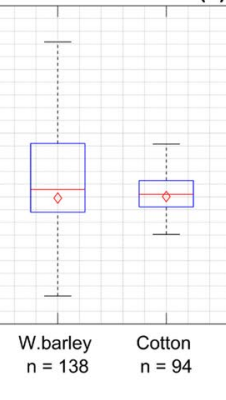

(b). Log yield ratio of NT/CT for different crops

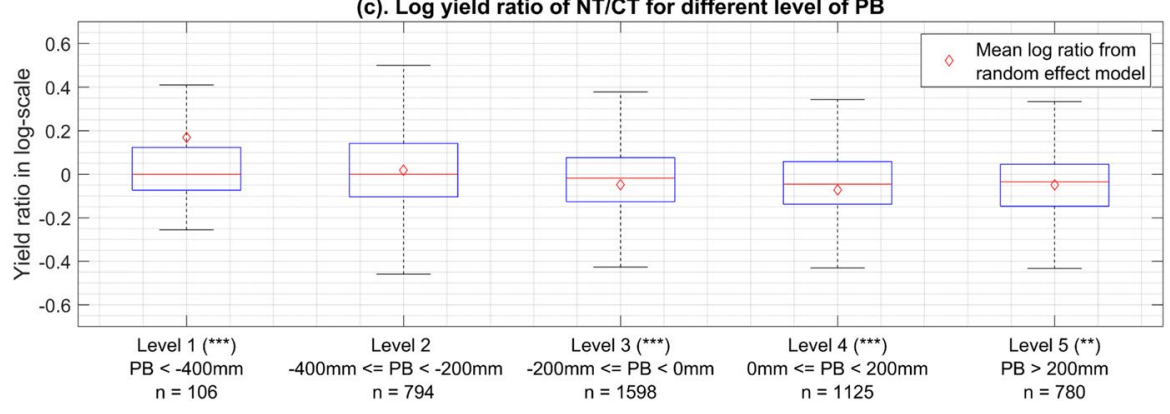

Fig. 4 Comparison of crop yield between NT and CT systems. The boxplots indicate the distributions (min, $1^{\text {st }}$ quartile, median, $3^{\text {rd }}$ quartile, max) of the log yield ratio of NT to CT. The mean log yield ratios of NT to CT were calculated based on a linear mixed effect model and marked as the red diamonds in the boxplots. Statistical tests were conducted to test the significance of the estimated values, $* * *$ indicates $\mathrm{P}$-value $<0.001$, $* *$ indicates $\mathrm{P}$-value $<0.01$, *indicates $\mathrm{P}$-value $<0.05$, indicates $\mathrm{P}$-value $<0.1$. Plot (a) shows the mean $\log$ ratios for different types of NT systems vs. CT systems. $N T_{\text {overal }}$ represents all the experiments involving NT systems in the dataset, $N T_{-R-S C}$ represents the NT systems without crop rotation and without soil cover, $N T_{+R+S C}$ represents the CA systems or NT systems with both crop rotation and soil cover, and CT is the corresponding control in the experiments. Plot (b) shows the mean log ratios for different crop species. S. indicates spring, while W. indicates winter. Plot (c) shows the mean log ratios for different levels of PBs, corresponding to different level of water stress.

NT practice without rotation and soil cover (Fig. 4a), which is also in line with previous studies ${ }^{1,16,37}$. Further analysis conducted on each crop confirms that NT tends to decrease the yield of maize ${ }^{1}$, rice ${ }^{21}$, and wheat ${ }^{1}$ (Fig. 4b). The productivity of NT is found higher under dry conditions compared with wetter conditions (Fig. 4c), and similar trends were reported in previous studies ${ }^{1,12}$.

Usage notes. Our dataset can be used to analyze the factors influencing the productivity of NT (or CA) vs. CT. It is possible to train machine learning models to predict the probability of yield increase with NT (or CA) system (e.g. Supplementary Figs. 1 and 2) or the range of yield changes resulting based on the soil type, climate and agronomic inputs provided by this dataset. Global maps of probability of yield increase with NT (or CA) or the range of yield changes can be generated based on the outputs of machine learning models trained with our dataset, and enable policy-makers or agricultural advisors to identify the most promising regions for CA implementation. Details of how to train machine leaning models with our dataset are provided in Supplementary Materials ${ }^{38-450}$

The crop yield data for 2018 and later can be extracted from the identified papers, but since some key climatic variables are missing in the external database for this time period (in particular, evapotranspiration), those data are not listed in the dataset provided. We will update the dataset once we have the latest data access to the missing climate variables.

Importantly, our dataset could be easily updated using data produced by new experiments. We welcome anyone interested to share data or papers not included in this meta-database to send them to the corresponding author (YS, yang.su@inrae.fr). We will maintain and add the new observations in the future to expand our dataset with the latest experimental data.

\section{Code availability}

Scripts using the R and MATLAB programming language are provided to produce figures and extract data from external databases. Additional code and related files are available from the corresponding author upon request.

Received: 21 April 2020; Accepted: 16 December 2020;

Published: 28 January 2021 


\section{References}

1. Pittelkow, C. M. et al. When does no-till yield more? A global meta-analysis. Field Crops Research 183, 156-168 (2015).

2. Food and Agriculture Organization of the United Nations (FAO). Save and grow: A policymaker's guide to the sustainable intensification of smallholder crop production. http://www.fao.org/3/a-i2215e.pdf (2011).

3. Farooq, M. \& Kadambot H. M. Siddique. CONSERVATION AGRICULTURE (Springer, 2015).

4. Holland, J. M. The environmental consequences of adopting conservation tillage in Europe: Reviewing the evidence. Agriculture, Ecosystems and Environment 103, 1-25 (2004).

5. Govaerts, B. et al. Infiltration, soil moisture, root rot and nematode populations after 12 years of different tillage, residue and crop rotation managements. Soil and Tillage Research 94, 209-219 (2007).

6. Michler, J. D., Baylis, K., Arends-Kuenning, M. \& Mazvimavi, K. Conservation agriculture and climate resilience. Journal of Environmental Economics and Management 93, 148-169 (2019).

7. Brouder, S. M. \& Gomez-Macpherson, H. The impact of conservation agriculture on smallholder agricultural yields: A scoping review of the evidence. Agriculture, Ecosystems \& Environment 187, 11-32 (2014).

8. Smith, P. \& Powlson, D. S. Glendining, M. J. \& Smith, Jo. U. Preliminary estimates of the potential for carbon mitigation in European soils through no-till farming. Global Change Biology 4, 679-685 (1998).

9. Lal, R. \& Stewart, B. A. Food security and soil quality (CRC Press, 2010).

10. Liu, E. K. et al. Effects of no-tillage management on soil biochemical characteristics in northern China. The Journal of Agricultural Science 148, 217-223 (2010).

11. Jat, S. L. et al. Differential response from nitrogen sources with and without residue management under conservation agriculture on crop yields, water-use and economics in maize-based rotations. Field Crops Research 236, 96-110 (2019).

12. Steward, P. R. et al. The adaptive capacity of maize-based conservation agriculture systems to climate stress in tropical and subtropical environments: A meta-regression of yields. Agriculture, Ecosystems and Environment 251, 194-202 (2018).

13. Nichols, V., Verhulst, N., Cox, R. \& Govaerts, B. Weed dynamics and conservation agriculture principles: A review. Field Crops Research 183, 56-68 (2015).

14. Sepat, S. et al. Effects of weed control strategy on weed dynamics, soybean productivity and profitability under conservation agriculture in India. Field Crops Research 210, 61-70 (2017).

15. Boomsma, C. R. et al. Maize grain yield responses to plant height variability resulting from crop rotation and tillage system in a long-term experiment. Soil and Tillage Research 106, 227-240 (2010).

16. Scopel, E. et al. Conservation agriculture cropping systems in temperate and tropical conditions, performances and impacts. A review. Agronomy for Sustainable Development 33, 113-130 (2013).

17. Corbeels, M., Cardinael, R., Naudin, K., Guibert, H. \& Torquebiau, E. The 4 per 1000 goal and soil carbon storage under agroforestry and conservation agriculture systems in sub-Saharan Africa. Soil and Tillage Research 188, 16-26 (2019).

18. Corbeels, M., Sakyi, R. K., Kühne, R. F. and Whitbread, A. 2014. Meta-analysis of crop responses to conservation agriculture in sub-Saharan Africa. CCAFS Report No. 12. Copenhagen: CGIAR Research Program on Climate Change, Agriculture and Food Security (CCAFS). www.ccafs.cgiar.org (2020).

19. Zheng, C. et al. The impacts of conservation agriculture on crop yield in China depend on specific practices, crops and cropping regions. The Crop. Journal 2, 289-296 (2014).

20. Laborde, J. P., Wortmann, C. S., Blanco-Canqui, H., Baigorria, G. A. \& Lindquist, J. L. Identifying the drivers and predicting the outcome of conservation agriculture globally. Agricultural Systems 177, 102692 (2020).

21. Knapp, S. \& van der Heijden, M. G. A. A global meta-analysis of yield stability in organic and conservation agriculture. Nature Communications 9, 1-9 (2018).

22. Pittelkow, C. M. et al. Productivity limits and potentials of the principles of conservation agriculture. Nature 517, 365-368 (2015).

23. van den Putte, A., Govers, G., Diels, J., Gillijns, K. \& Demuzere, M. Assessing the effect of soil tillage on crop growth: A metaregression analysis on European crop yields under conservation agriculture. European Journal of Agronomy 33, 231-241 (2010).

24. Brouder, S. M. \& Gomez-Macpherson, H. The impact of conservation agriculture on smallholder agricultural yields: A scoping review of the evidence. Agriculture, Ecosystems and Environment 187, 11-32 (2014).

25. Farooq, M., Flower, K. C., Jabran, K., Wahid, A. \& Siddique, K. H. M. Crop yield and weed management in rainfed conservation agriculture. Soil and Tillage Research 117, 172-183 (2011).

26. University of Wisconsin-Madison. Crop Calendar Dataset: netCDF 5 min | SAGE, UW-Madison. https://nelson.wisc.edu/sage/ data-and-models/crop-calendar-dataset/netCDF0-5degree.php (2020).

27. Sacks, W. J., Deryng, D., Foley, J. A. \& Ramankutty, N. Crop planting dates: an analysis of global patterns. Global Ecology and Biogeography (2010).

28. NOAA/OAR/ESRL PSL. University of Delaware Air Temperature \& Precipitation. https://www.esrl.noaa.gov/psd/data/gridded/ data.UDel_AirT_Precip.html (2020).

29. NOAA/OAR/ESRL PSL. CPC Global Daily Temperature. https://www.esrl.noaa.gov/psd/data/gridded/data.cpc.globaltemp.html (2020).

30. Martens, B. et al. GLEAM v3: satellite-based land evaporation and root-zone soil moisture. Geoscientific Model. Development 10, 1903-1925 (2017).

31. Miralles, D. G. et al. Global land-surface evaporation estimated from satellite-based observations. Hydrology and Earth System Sciences 15, 453-469 (2011).

32. University of Tokyo. Soil Texture Map. http://hydro.iis.u-tokyo.ac.jp/ sujan/research/gswp3/soil-texture-map.html (2020).

33. Su, Y., Gabrielle, B. \& Makowski, D. A global dataset for crop production under conventional tillage and no tillage systems. figshare https://doi.org/10.6084/m9.figshare.12155553 (2020).

34. Food and Agriculture Organization of the United Nations (FAO). Conservation Agriculture. http://www.fao.org/conservationagriculture/en/ (2020).

35. Rudolf J., F, William, J. Wilson \& Donna L. Mohr. STATISTICAL METHODS. (Elsevier, 2010).

36. Lee, H. et al. The impact of conservation farming practices on Mediterranean agro-ecosystem services provisioning-a metaanalysis. Regional Environmental Change 19, 2187-2202 (2019).

37. Mtaita, T. A. Food. in Field Guide to Appropriate Technology 277-480 (Elsevier, 2003).

38. Aase, J. K., Schaefer, G. M. \& Pikul, J. L. Hayland conversion to wheat production in semiarid eastern Montana: Tillage, yield and hay production comparisons. Soil and Tillage Research 44, 225-234 (1997).

39. Acharya, B. S. et al. Winter cover crops effect on soil moisture and soybean growth and yield under different tillage systems. Soil and Tillage Research 195, 104430 (2019).

40. Adimassu, Z., Alemu, G. \& Tamene, L. Effects of tillage and crop residue management on runoff, soil loss and crop yield in the Humid Highlands of Ethiopia. Agricultural Systems 168, 11-18 (2019).

41. Ahmed, W. et al. Tillage practices improve rice yield and soil phosphorus fractions in two typical paddy soils. Journal of Soils and Sediments 20, 850-861 (2020).

42. Ahrens, W. H. \& Endres, G. J. Trifluralin and ethalfluralin granules in conservation-tillage soybeans (Glycine max). Canadian Journal of Plant Science 76, 891-897 (1996).

43. Alam, M. K. et al. Banding of fertilizer improves phosphorus acquisition and yield of zero tillage maize by concentrating phosphorus in surface soil. Sustainability (Switzerland) 10 (2018). 
44. Ali, S. A., Tedone, L., Verdini, L., Cazzato, E. \& De Mastro, G. Wheat response to no-tillage and nitrogen fertilization in a long-term faba bean-based rotation. Agronomy 9 (2019).

45. Almaraz, J. J. et al. Carbon Dioxide and Nitrous Oxide Fluxes in Corn Grown under Two Tillage Systems in Southwestern Quebec. Soil Science Society of America Journal 73, 113-119 (2009).

46. Almaraz, J. J. et al. Greenhouse gas fluxes associated with soybean production under two tillage systems in southwestern Quebec. Soil and Tillage Research 104, 134-139 (2009).

47. Anapalli, S. S. et al. Effectiveness of RZWQM for simulating alternative great plains cropping systems. Agronomy Journal 97, 1183-1193 (2005).

48. Andales, A. A., Batchelor, W. D., Anderson, C. E., Farnham, D. E. \& Whigham, D. K. Incorporating tillage effects into a soybean model. Agricultural Systems 66, 69-98 (2000).

49. Anderson, R. L. A 2-Year Small Grain Interval Reduces Need for Herbicides in No-Till Soybean. Weed Technology 23, 398-403 (2009).

50. Angás, P., Lampurlanés, J. \& Cantero-Martínez, C. Tillage and $\mathrm{N}$ fertilization: Effects on $\mathrm{N}$ dynamics and Barley yield under semiarid Mediterranean conditions. Soil and Tillage Research 87, 59-71 (2006).

51. Armstrong, R. D., Millar, G., Halpin, N. V., Reid, D. J. \& Standley, J. Using zero tillage, fertilisers and legume rotations to maintain productivity and soil fertility in opportunity cropping systems on a shallow Vertosol. Australian Journal of Experimental Agriculture 43, 141-153 (2003).

52. Arora, V. K., Sidhu, A. S., Sandhu, K. S. \& Thind, S. S. Effects of tillage intensity, planting time and nitrogen rate on wheat yield following rice. Experimental Agriculture 46, 267-275 (2010).

53. Arshad, M. A. \& Gill, K. S. Barley, canola and wheat production under different tillage-fallow-green manure combinations on a clay soil in a cold, semiarid climate. Soil and Tillage Research 43, 263-275 (1997).

54. Arshad, M. A., Gill, K. S. \& Coy, G. R. Wheat yield and weed population as influenced by three tillage systems on a clay soil in temperate continental climate. Soil and Tillage Research 28, 227-238 (1994).

55. Arshad, M. A., Gill, K. S. \& Izaurralde, R. C. Wheat Production, Weed Population and Soil Properties Subsequent to 20 Years of Sod as Affected by Crop Rotation and Tillage. Journal of Sustainable Agriculture 12, 131-154 (1998).

56. Arvidsson, J. Energy use efficiency in different tillage systems for winter wheat on a clay and silt loam in Sweden. European Journal of Agronomy 33, 250-256 (2010).

57. Aulakh, M. S. et al. Crop production and nutrient use efficiency of conservation agriculture for soybean-wheat rotation in the Indo-Gangetic Plains of Northwestern India. Soil and Tillage Research 120, 50-60 (2012).

58. Azooz, R. H. \& Arshad, M. A. Effect of tillage and residue management on barley and canola growth and water use efficiency. Canadian Journal of Soil Science 78, 649-656 (1998).

59. Baan, C. D., Grevers, M. C. J. \& Schoenau, J. J. Effects of a single cycle of tillage on long-term no-till prairie soils. Canadian Journal of Soil Science 89, 521-530 (2009).

60. Baggs, E. M. et al. Nitrous oxide emissions following application of residues and fertiliser under zero and conventional tillage. Plant and Soil 254, 361-370 (2003).

61. Baghdadi, A., Halim, R. A., Majidian, M., Wan Daud, W. N. \& Ahmad, I. Forage corn yield and physiological indices under different plant densities and tillage systems. Journal of Food, Agriculture and Environment 10, 707-712 (2012).

62. Bailey, K. L., Johnston, A. M., Kutcher, H. R., Gossen, B. D. \& Morrall, R. A. A. Managing crop losses from foliar diseases with fungicides, rotation, and tillage in the Saskatchewan Parkland. Canadian Journal of Plant Science 80, 169-175 (2000).

63. Bajpai, R. K. \& Tripathi, R. P. Evaluation of non-puddling under shallow water tables and alternative tillage methods on soil and crop parameters in a rice-wheat system in Uttar Pradesh. Soil and Tillage Research 55, 99-106 (2000).

64. Balkcom, K. S., Reeves, D. W., Kemble, J. M., Dawkins, R. A. \& Raper, R. L. Tillage requirements of sweet corn, field pea, and watermelon following stocker cattle grazing. Journal of Sustainable Agriculture 34, 169-182 (2010).

65. Balkcom, K. S. et al. Row spacing, tillage system, and herbicide technology affects cotton plant growth and yield. Field Crops Research 117, 219-225 (2010).

66. Ball, B. C., O'Sullivan, M. F. \& Lang, R. W. Cultivation and nitrogen requirement for winter barley as assessed from a reducedtillage experiment on a brown forest soil. Soil and Tillage Research 6, 95-109 (1985).

67. Barber, R. G., Orellana, M., Navarro, F., Diaz, O. \& Soruco, M. A. Effects of conservation and conventional tillage systems after land clearing on soil properties and crop yield in Santa Cruz, Bolivia. Soil and Tillage Research 38, 133-152 (1996).

68. Barrios, M. B., Bozzo, A. A., Debelis, S. P., Pereyra, A. M. \& Buján, A. Soil physical properties and root activity in a soybean second crop/maize rotation under direct sowing and conventional tillage. Spanish Journal of Agricultural Research 4, 355-362 (2006).

69. Baumhardt, R. L. \& Jones, O. R. Residue management and tillage effects on soil-water storage and grain yield of dryland wheat and sorghum for a clay loam in Texas. Soil and Tillage Research 68, 71-82 (2002).

70. Baumhardt, R. L., Wendt, C. W. \& Keeling, J. W. Tillage and furrow diking effects on water balance and yields of sorghum and cotton. Soil Science Society of America Journal 57, 1077-1083 (1993).

71. Behnke, G. D., Zuber, S. M., Pittelkow, C. M., Nafziger, E. D. \& Villamil, M. B. Long-term crop rotation and tillage effects on soil greenhouse gas emissions and crop production in Illinois, USA. Agriculture, Ecosystems \& Environment 261, 62-70 (2018).

72. Bermudez, M. \& Mallarino, A. P. Corn response to starter fertilizer and tillage across and within fields having no-till management histories. Agronomy Journal 96, 776-785 (2004).

73. Bernstein, E. R., Posner, J. L., Stoltenberg, D. E. \& Hedtcke, J. L. Organically managed no-tillage rye-soybean systems: agronomic, economic, and environmental assessment. Agronomy Journal 103, 1169-1179 (2011).

74. Beyaert, R. P., Schott, J. W. \& White, P. H. Tillage effects on corn production in a coarse-textured soil in Southern Ontario. Agronomy Journal 94, 767-774 (2002).

75. Bisen, P. K. \& Singh, R. Effect of tillage and weed control practices on weed growth and yield of wheat (Triticum aestivum) in rice (Oryza sativa) - Wheat system. Indian Journal of Agricultural Sciences 78, 347-350 (2008).

76. Blackshaw, R. E., Semach, G., Li, X., O’Donovan, J. T. \& Harker, K. N. Tillage, fertiliser and glyphosate timing effects on foxtail barley (Hordeum jubatum) management in wheat. Canadian Journal of Plant Science 80, 655-660 (2000).

77. Bocianowski, J., Szulc, P. \& Nowosad, K. Soil tillage methods by years interaction for dry matter of plant yield of maize (Zea mays L.) using additive main effects and multiplicative interaction model. Journal of Integrative Agriculture 17, 2836-2839 (2018).

78. Boeckx, P. \& Van Nieuland, K. \& Van Cleemput, O. Short-term effect of tillage intensity on $\mathrm{N}_{2} \mathrm{O}$ and $\mathrm{CO}_{2}$ emissions. Agronomy for Sustainable Development 31, 453-461 (2011).

79. Boehmel, C., Lewandowski, I. \& Claupein, W. Comparing annual and perennial energy cropping systems with different management intensities. Agricultural Systems 96, 224-236 (2008).

80. Bogunovic, I., Pereira, P., Kisic, I., Sajko, K. \& Sraka, M. Tillage management impacts on soil compaction, erosion and crop yield in Stagnosols (Croatia). CATENA 160, 376-384 (2018).

81. Bono, A., Alvarez, R., Buschiazzo, D. E. \& Cantet, R. J. C. Tillage effects on soil carbon balance in a semiarid agroecosystem. Soil Science Society of America Journal 72, 1140-1149 (2008).

82. Bordovsky, J. P., Lyle, W. M. \& Keeling, J. W. Crop rotation and tillage rffects on soil water and cotton yield. Agronomy Journal 86, 1-6 (1994).

83. Botta, G. F., Tolon-Becerra, A., Lastra-Bravo, X. \& Tourn, M. Tillage and traffic effects (planters and tractors) on soil compaction and soybean (Glycine max L.) yields in Argentinean pampas. Soil and Tillage Research 110, 167-174 (2010). 
84. Brandt, S. A. Zero vs. conventional tillage and their effects on crop yield and soil moisture. Canadian Journal of Plant Science 72, 679-688 (1992).

85. Brown, V., Barbosa, F. T., Bertol, I., Mafra, Á. L. \& Muzeka, L. M. Effects on soil and crops after 20 years of conventional and zero tillage. Revista Brasileirade Ciencias Agrarias 13, 1-7 (2018).

86. Büchi, L., Wendling, M., Amossé, C., Necpalova, M. \& Charles, R. Importance of cover crops in alleviating negative effects of reduced soil tillage and promoting soil fertility in a winter wheat cropping system. Agriculture, Ecosystems \& Environment 256, 92-104 (2018).

87. Busscher, W. J., Khalilian, A. \& Jones, M. A. Tillage Management for Cotton in Southeastern Coastal Soils during Dry Years. Communications in Soil Science and Plant Analysis 43, 2564-2574 (2012).

88. Cahoon, J. E. et al. Corn Yield Response to Tillage with Furrow Irrigation. Journal of Production Agriculture 12, $269-275$ (1999).

89. Calzarano, F. et al. Durum Wheat Quality, Yield and Sanitary Status under Conservation Agriculture. Agriculture 8, 140 (2018).

90. Camarotto, C. et al. Conservation agriculture and cover crop practices to regulate water, carbon and nitrogen cycles in the lowlying Venetian plain. Catena 167, 236-249 (2018).

91. Campbell, C. et al. Converting from no-tillage to pre-seeding tillage: Influence on weeds, spring wheat grain yields and N, and soil quality. Soil and Tillage Research 46, 175-185 (1998).

92. Campbell, D. J., Dickson, J. W., Ball, B. C. \& Hunter, R. Controlled seedbed traffic after ploughing or direct drilling under winter barley in Scotland, 1980-1984. Soil and Tillage Research 8, 3-28 (1986).

93. Cannell, R. Q., Christian, D. G. \& Henderson, F. K. G. A study of mole drainage with simplified cultivation for autumn-sown crops on a clay soil. 4. A comparison of direct drilling and mouldboard ploughing on drained and undrained land on root and shoot growth, nutrient uptake and yield. Soil and Tillage Research 7, 251-272 (1986).

94. Cantero-Martínez, C., Angás, P. \& Lampurlanés, J. Long-term yield and water use efficiency under various tillage systems in Mediterranean rainfed conditions. Annals of Applied Biology 150, 293-305 (2007).

95. Carefoot, J. M., Nyborg, M. \& Lindwall, C. W. Tillage-induced soil changes and related grain yield in a semi-arid region. Canadian Journal of Soil Science 70, 203-214 (1990).

96. Carignano, M., Staggenborg, S. A. \& Shroyer, J. P. Management practices to minimize tan spot in a continuous wheat rotation. Agronomy Journal 100, 145-153 (2008).

97. Carof, M., Tourdonnet, S., Saulas, P., Floch, D. \& Roger-Estrade, J. Undersowing wheat with different living mulches in a no-till system. I. Yield analysis. Agronomy for Sustainable Development 27, 347-356 (2007).

98. Cassel, D. K., Raczkowski, C. W. \& Denton, H. P. Tillage effects on corn production and soil physical conditions. Soil Science Society of America Journal 59, 1436-1443 (1995).

99. Cavigelli, M. A., Teasdale, J. R. \& Conklin, A. E. Long-term agronomic performance of organic and conventional field crops in the Mid-Atlantic region. Agronomy Journal 100, 785-794 (2008).

100. Celik, I. et al. Impacts of different tillage practices on some soil microbiological properties and crop yield under semi-arid Mediterranean conditions. International Journal of Plant Production 5, 237-254 (2011).

101. Chatskikh, D. \& Olesen, J. E. Soil tillage enhanced $\mathrm{CO}_{2}$ and $\mathrm{N}_{2} \mathrm{O}$ emissions from loamy sand soil under spring barley. Soil and Tillage Research 97, 5-18 (2007).

102. Chauhan, B. S. \& Opeña, J. Effect of tillage systems and herbicides on weed emergence, weed growth, and grain yield in dry-seeded rice systems. Field Crops Research 137, 56-69 (2012).

103. Chen, S. Y., Stienstra, W. C., Lueschen, W. E. \& Hoverstad, T. R. Response of heterodera glycines and soybean cultivar to tillage and row spacing. Plant Disease 85, 311-316 (2001).

104. Chen, S. Tillage and crop sequence effects on heterodera glycines and soybean yields. Agronomy Journal 99, 797-807 (2007).

105. Chikoye, D., Udensi, U. E. \& Ogunyemi, S. Integrated management of cogongrass [imperata cylindrica (L.) rauesch.] in corn using tillage, glyphosate, row spacing, cultivar, and cover cropping. Agronomy Journal 97, 1164-1171 (2005).

106. Christian, D. G. \& Bacon, E. T. G. A long-term comparison of ploughing, tine cultivation and direct drilling on the growth and yield of winter cereals and oilseed rape on clayey and silty soils. Soil and Tillage Research 18, 311-331 (1990).

107. Cline, G. R. \& Silvernail, A. F. Effects of cover crops, nitrogen, and tillage on sweet corn. Hort Technology 12, 118-125 (2002).

108. Cociu, A. I. Long-term tillage and crop sequence effects on Winter Wheat and Triticale grain yield under eastern Romanian danube plain climate conditions. Romanian Agricultural Research 2019 (2019).

109. Cociu, A. I. Long-term tillage and crop sequence effects on Maize and Soybean grain yield under eastern Romanian danube plain climate conditions. Romanian Agricultural Research 2019 (2019).

110. Costa, S. E. V. G. A. et al. Patterns in phosphorus and corn root distribution and yield in long-term tillage systems with fertilizer application. Soil and Tillage Research 109, 41-49 (2010).

111. Coventry, D. R., Hirth, J. R. \& Reeves, T. G. Interactions of tillage and lime in wheat-subterranean clover rotations on an acidic sandy clay loam in southeastern Australia. Soil and Tillage Research 25, 53-65 (1992).

112. Cox, W. J., Zobel, R. W., van Es, H. M. \& Otis, D. J. Growth development and yield of maize under three tillage systems in the northeastern USA. Soil and Tillage Research 18, 295-310 (1990).

113. Cullum, R. F. Influence of tillage on maize yield in soil with shallow fragipan. Soil and Tillage Research 119, 1-6 (2012).

114. Erbach, D. C. et al. Maize response to tillage-induced soil conditions. Transactions of the ASAE 29, 0690-0695 (1986).

115. Daigh, A. L. M. et al. Yields and yield stability of no-till and chisel-plow fields in the Midwestern US Corn Belt. Field Crops Research 218, 243-253 (2018)

116. Dam, R. F. et al. Soil bulk density and crop yield under eleven consecutive years of corn with different tillage and residue practices in a sandy loam soil in central Canada. Soil and Tillage Research 84, 41-53 (2005).

117. Das, T. K. et al. Conservation agriculture effects on crop and water productivity, profitability and soil organic carbon accumulation under a maize-wheat cropping system in the North-western Indo-Gangetic Plains. Field Crops Research 215, 222-231 (2018).

118. de Cárcer, P. S., Sinaj, S., Santonja, M., Fossati, D. \& Jeangros, B. Long-term effects of crop succession, soil tillage and climate on wheat yield and soil properties. Soil and Tillage Research 190, 209-219 (2019).

119. De Vita, P., Di Paolo, E., Fecondo, G., Di Fonzo, N. \& Pisante, M. No-tillage and conventional tillage effects on durum wheat yield, grain quality and soil moisture content in southern Italy. Soil and Tillage Research 92, 69-78 (2007).

120. Decker, J. E., Epplin, F. M., Morley, D. L. \& Peeper, T. F. Economics of five wheat production systems with no-till and conventional tillage. Agronomy Journal 101, 364-372 (2009).

121. Dekemati, I., Simon, B., Vinogradov, S. \& Birkás, M. The effects of various tillage treatments on soil physical properties, earthworm abundance and crop yield in Hungary. Soil and Tillage Research 194, 104334 (2019).

122. Díaz-Zorita, M. Effect of deep-tillage and nitrogen fertilization interactions on dryland corn (Zea mays L.) productivity. Soil and Tillage Research 54, 11-19 (2000).

123. Díaz-Zorita, M., Grove, J. H., Murdock, L., Herbeck, J. \& Perfect, E. Soil Structural Disturbance Effects on Crop Yields and Soil Properties in a No-Till Production System. Agronomy Journal 96, 1651-1659 (2004).

124. Díaz-Zorita, M., Duarte, G. A. \& Grove, J. H. A review of no-till systems and soil management for sustainable crop production in the subhumid and semiarid Pampas of Argentina. Soil and Tillage Research 65, 1-18 (2002).

125. Dickey, E. C., Jasa, P. J. \& Grisso, R. D. Long term tillage effects on grain yield and soil properties in a soybean/grain sorghum rotation. Journal of Production Agriculture 7, 465-470 (1994). 
126. Dixit, A. K. et al. Soil properties, crop productivity and energetics under different tillage practices in fodder sorghum + cowpea-wheat cropping system. Archives of Agronomy and Soil Science 65, 492-506 (2019).

127. Domínguez, G. F., Diovisalvi, N. V., Studdert, G. A. \& Monterubbianesi, M. G. Soil organic C and N fractions under continuous cropping with contrasting tillage systems on mollisols of the southeastern Pampas. Soil and Tillage Research 102, 93-100 (2009).

128. Donald, P. A., Tyler, D. D. \& Boykin, D. L. Short- and long-term tillage effects on Heterodera glycines reproduction in soybean monoculture in west Tennessee. Soil and Tillage Research 104, 126-133 (2009).

129. Drinkwater, L. E., Janke, R. R. \& Rossoni-Longnecker, L. Effects of tillage intensity on nitrogen dynamics and productivity in legume-based grain systems. Plant and Soil 227, 99-113 (2000).

130. Drury, C. F. et al. Emissions of nitrous oxide and carbon dioxide: influence of tillage type and nitrogen placement depth. Soil Science Society of America Journal 70, 570-581 (2006).

131. Drury, C. F. et al. Impacts of zone tillage and red clover on corn performance and soil physical quality. Soil Science Society of America Journal 67, 867-877 (2003).

132. Drury, C. F. et al. Nitrogen Source, Application Time, and Tillage Effects on Soil Nitrous Oxide Emissions and Corn Grain Yields. Soil Science Society of America Journal 76, 1268-1279 (2012).

133. Duiker, S. W. \& Curran, W. S. Rye cover crop management for corn production in the Northern Mid-Atlantic region. Agronomy Journal 97, 1413-1418 (2005).

134. Edwards, J. H., Thurlow, D. L. \& Eason, J. T. Influence of tillage and crop rotation on yields of corn, soybean, and wheat. Agronomy Journal 80, 76 (1988).

135. Eghball, B. \& Power, J. F. Composted and noncomposted manure application to conventional and no-tillage systems: corn yield and nitrogen uptake. Agronomy Journal 91, 819-825 (1999).

136. Ellington, A. Effects of deep ripping, direct drilling, gypsum and lime on soils, wheat growth and yield. Soil and Tillage Research $\mathbf{8}$, 29-49 (1986).

137. Endale, D. M. et al. Impact of conservation tillage and nutrient management on soil water and yield of cotton fertilized with poultry litter or ammonium nitrate in the Georgia Piedmont. Soil and Tillage Research 66, 55-68 (2002).

138. Endale, D. M. et al. No-till corn productivity in a southeastern United States ultisol amended with poultry litter. Agronomy Journal 100, 1401-1408 (2008).

139. Ernani, P. R., Bayer, C. \& Maestri, L. Corn yield as affected by liming and tillage system on an acid Brazilian Oxisol. Agronomy Journal 94, 305-309 (2002).

140. Fecák, P., Šariková, D. \& Černý, I. Influence of tillage system and starting $\mathrm{N}$ fertilization on seed yield and quality of soybean Glycine $\max$ (L.) Merrill. Plant, Soil and Environment 56, 105-110 (2010).

141. Feng, F. X., Huang, G. B., Chai, Q. \& Yu, A. Z. Tillage and straw management impacts on soil properties, root growth, and grain yield of winter wheat in northwestern china. Crop Science 50, 1465-1473 (2010)

142. Fengyun, Z., Pute, W., Xining, Z., Enhe, Z. \& Xuefeng, C. Effects of conservation tillage on soil water regimes and water use efficiency in farmland of Heihe River Basin in Northwest China. African Journal of Agricultural Research 6, 5959-5966 (2011).

143. Filipovic, D., Husnjak, S., Kosutic, S. \& Gospodaric, Z. Effects of tillage systems on compaction and crop yield of Albic Luvisol in Croatia. Journal of Terramechanics 43, 177-189 (2006).

144. Fiorini, A., Maris, S. C., Abalos, D., Amaducci, S. \& Tabaglio, V. Combining no-till with rye (Secale cereale L.) cover crop mitigates nitrous oxide emissions without decreasing yield. Soil and Tillage Research 196, 104442 (2020).

145. Fischer, R. A., Santiveri, F. \& Vidal, I. R. Crop rotation, tillage and crop residue management for wheat and maize in the sub-humid tropical highlands I. Wheat and legume performance. Field Crops Research 79, 107-122 (2002).

146. Fischer, R. A., Santiveri, F. \& Vidal, I. R. Crop rotation, tillage and crop residue management for wheat and maize in the sub-humid tropical highlands II. Maize and system performance. Field Crops Research 79, 123-137 (2002).

147. Flowers, M. D. \& Lal, R. Axle load and tillage effects on soil physical properties and soybean grain yield on a mollic ochraqualf in northwest Ohio. Soil and Tillage Research 48, 21-35 (1998).

148. Franchini, J. C. et al. Evolution of crop yields in different tillage and cropping systems over two decades in southern Brazil. Field Crops Research 137, 178-185 (2012).

149. Franzluebbers, A. J. \& Stuedemann, J. A. Crop and cattle responses to tillage systems for integrated crop-livestock production in the Southern Piedmont, USA. Renewable Agriculture and Food Systems 22, 168-180 (2007).

150. Gajri, P. R., Arora, V. K. \& Prihar, S. S. Tillage management for efficient water and nitrogen use in wheat following rice. Soil and Tillage Research 24, 167-182 (1992).

151. Galvez, L., Douds, D. D., Drinkwater, L. E. \& Wagoner, P. Effect of tillage and farming system upon VAM fungus populations and mycorrhizas and nutrient uptake of maize. Plant and Soil 228, 299-308 (2001).

152. Galvez, L., Douds, D. D. \& Wagoner, P. Tillage and farming system affect AM fungus populations, mycorrhizal formation, and nutrient uptake by winter wheat in a high-P soil. American Journal of Alternative Agriculture 16, 152-160 (2001).

153. Gangwar, K. S., Singh, K. K., Sharma, S. K. \& Tomar, O. K. Alternative tillage and crop residue management in wheat after rice in sandy loam soils of Indo-Gangetic plains. Soil and Tillage Research 88, 242-252 (2006).

154. Gangwar, K. S., Singh, K. K. \& Sharma, S. K. Effect of tillage on growth, yield and nutrient uptake in wheat after rice in the IndoGangetic Plains of India. The Journal of Agricultural Science 142, 453-459 (2004).

155. Gao, J., Hao, X., Thelen, K. D. \& Robertson, G. P. Agronomic management system and precipitation effects on soybean oil and fatty acid profiles. Crop Science 49, 1049-1057 (2009).

156. Gathala, M. K. et al. Effect of tillage and crop establishment methods on physical properties of a medium-textured soil under a seven-year rice-wheat rotation. Soil Science Society of America Journal 75, 1851-1862 (2011).

157. Ghuman, B. Tillage and residue management effects on soil properties and yields of rainfed maize and wheat in a subhumid subtropical climate. Soil and Tillage Research 58, 1-10 (2001).

158. Giannitsopoulos, M. L., Burgess, P. J. \& Rickson, R. J. Effects of conservation tillage systems on soil physical changes and crop yields in a wheat-oilseed rape rotation. Journal of Soil and Water Conservation 74, 247-258 (2019).

159. Gracia-Romero, A. et al. Phenotyping conservation agriculture management effects on ground and aerial remote sensing assessments of maize hybrids performance in Zimbabwe. Remote Sensing 10, 349 (2018)

160. Grageda-Cabrera, O. A. et al. Fertilizer dynamics in different tillage and crop rotation systems in a Vertisol in Central Mexico. Nutrient Cycling in Agroecosystems 89, 125-134 (2011).

161. Grandy, A. S., Robertson, G. P. \& Thelen, K. D. Do productivity and environmental trade-offs justify periodically cultivating no-till cropping systems? Agronomy Journal 98, 1377-1383 (2006).

162. Grant, C. A. \& Bailey, L. D. The effect of $\mathrm{KCl}, \mathrm{KNO} 3$, and $\mathrm{CaCl} 2$ fertilization under conventional- and zero-till systems on common root rot, dry matter yield and grain yield of Heartland barley. Canadian Journal of Plant Science 74, 1-6 (1994).

163. Griffith, D. R., Kladivko, E. J., Mannering, J. V., West, T. D. \& Parsons, S. D. Long-Term Tillage and Rotation Effects on Corn Growth and Yield on High and Low Organic Matter, Poorly Drained Soils. Agronomy Journal 80, 599-605 (1988).

164. Grigoras, M. A., Popescu, A., Pamfil, D., Has, I. \& Gidea, M. Influence of no-tillage agriculture system and fertilization on wheat yield and grain protein and gluten contents. Journal of Food, Agriculture and Environment 10, 532-539 (2012).

165. Gruber, S., Pekrun, C., Möhring, J. \& Claupein, W. Long-term yield and weed response to conservation and stubble tillage in SW Germany. Soil and Tillage Research 121, 49-56 (2012). 
166. Gul, B., Marwat, K. B., Saeed, M., Hussain, Z. \& Ali, H. Impact of tillage, plant population and mulches on weed management and grain yield of maize. Pakistan Journal of Botany 46, 1603-1606 (2011).

167. Guo, Y. et al. Reduced irrigation and nitrogen coupled with no-tillage and plastic mulching increase wheat yield in maize-wheat rotation in an arid region. Field Crops Research 243, 107615 (2019).

168. Guy, S. O. \& Cox, D. B. Reduced tillage increases residue groundcover in subsequent dry pea and winter wheat crops in the Palouse region of Idaho. Soil and Tillage Research 66, 69-77 (2002).

169. Gwenzi, W., Gotosa, J., Chakanetsa, S. \& Mutema, Z. Effects of tillage systems on soil organic carbon dynamics, structural stability and crop yields in irrigated wheat (Triticum aestivum L.)-cotton (Gossypium hirsutum L.) rotation in semi-arid Zimbabwe. Nutrient Cycling in Agroecosystems 83, 211-221 (2009).

170. Halvorson, A. D., Black, A. L., Krupinsky, J. M., Merrill, S. D. \& Tanaka, D. L. Sunflower response to tillage and nitrogen fertilization under intensive cropping in a wheat rotation. Agronomy Journal 91, 637-642 (1999).

171. Halvorson, A. D., Black, A. L., Krupinsky, J. M. \& Merrill, S. D. Dryland winter wheat response to tillage and nitrogen within an annual cropping system. Agronomy Journal 91, 702-707 (1999).

172. Halvorson, A. D., Mosier, A. R., Reule, C. A. \& Bausch, W. C. Nitrogen and tillage effects on irrigated continuous corn yields. Agronomy Journal 98, 63-71 (2006).

173. Halwani, M., Reckling, M., Schuler, J., Bloch, R. \& Bachinger, J. Soybean in no-till cover-crop systems. Agronomy 9, 883 (2019).

174. Hamblin, A. P. The effect of tillage on soil surface properties and the water balance of a xeralfic alfisol. Soil and Tillage Research 4, 543-559 (1984).

175. He, W. et al. Estimating the impacts of climate change on crop yields and $\mathrm{N} 2 \mathrm{O}$ emissions for conventional and no-tillage in Southwestern Ontario, Canada. Agricultural Systems 159, 187-198 (2018).

176. Hemmat, A. \& Eskandari, I. Dryland winter wheat response to conservation tillage in a continuous cropping system in northwestern Iran. Soil and Tillage Research 86, 99-109 (2006).

177. Hemmat, A. \& Eskandari, I. Tillage system effects upon productivity of a dryland winter wheat-chickpea rotation in the northwest region of Iran. Soil and Tillage Research 78, 69-81 (2004).

178. Hendrix, B. J., Young, B. G. \& Chong, S. K. Weed management in strip tillage corn. Agronomy Journal 96, 229-235 (2004).

179. Holanda, F. S. R. et al. Contribution of tillage systems on the organic matter of Gley soil and the productivity of corn and soybean. Semina:Ciencias Agrarias 32, 983-994 (2011).

180. Hou, X. et al. Effects of rotational tillage practices on soil properties, winter wheat yields and water-use efficiency in semi-arid areas of north-west China. Field Crops Research 129, 7-13 (2012).

181. Houria, C. et al. Tillage and residue management effect on durum wheat [Triticum turgidum (L.) thell. ssp. turgidum conv. durum (Desf.) mackey] growth and yield under semi arid climate. Advances in Environmental Biology 5, 3231-3240 (2011).

182. Houšt', M., Procházková, B. \& Hledík, P. Effect of different tillage intensity on yields and yieldforming factors in winter wheat. Acta Universitatis Agriculturae et Silviculturae Mendelianae Brunensis 60, 89-96 (2012).

183. Howard, D. D., Gwathmey, C. O., Roberts, R. K. \& Lessman, G. M. Potassium fertilization of cotton on two high testing soils under two tillage systems. Journal of Plant Nutrition 20, 1645-1656 (1997).

184. Hu, W. et al. Effects of tillage, compaction and nitrogen inputs on crop production and nitrogen losses following simulated forage crop grazing. Agriculture, Ecosystems and Environment $\mathbf{2 8 9}$ (2020).

185. Huang, G. B. et al. Productivity and sustainability of a spring wheat-field pea rotation in a semi-arid environment under conventional and conservation tillage systems. Field Crops Research 107, 43-55 (2008).

186. Huang, M., Jiang, P., Zhou, X. \& Zou, Y. No-tillage increases nitrogen scavenging by fallow weeds in a double-season rice cropping system in China. Weed Biology and Management 18, 105-109 (2018).

187. Huang, M. et al. No-tillage and direct seeding for super hybrid rice production in rice-oilseed rape cropping system. European Journal of Agronomy 34, 278-286 (2011).

188. Huang, M. et al. Effect of tillage on soil and crop properties of wet-seeded flooded rice. Field Crops Research 129, 28-38 (2012).

189. Huang, X., Wang, L., Yang, L. \& Kravchenko, A. N. Management effects on relationships of crop yields with topography represented by wetness index and precipitation. Agronomy Journal 100, 1463-1471 (2008).

190. Hunt, P. G., Bauer, P. J., Matheny, T. A. \& Busscher, W. J. Crop yield and nitrogen accumulation response to tillage of a coastal plain soil. Crop Science 44, 1673-1681 (2004).

191. Hussein, M. A. et al. Deep Tillage Improves Degraded Soils in the (Sub) Humid Ethiopian Highlands. Land 8, 159 (2019).

192. Huynh, H. T., Hufnagel, J., Wurbs, A. \& Bellingrath-Kimura, S. D. Influences of soil tillage, irrigation and crop rotation on maize biomass yield in a 9-year field study in Müncheberg, Germany. Field Crops Research 241, 107565 (2019).

193. Iijima, M., Asai, T., Zegada-Lizarazu, W., Nakajima, Y. \& Hamada, Y. Productivity and water source of intercropped wheat and rice in a direct-sown sequential cropping system: the effects of no-tillage and drought. Plant Production Science 8, 368-374 (2005).

194. Iqbal, M., Anwar-ul-Hassan \& Ibrahim, M. Effects of tillage systems and mulch on soil physical quality parameters and maize (Zea mays L.) yield in semi-arid Pakistan. Biological Agriculture \& Horticulture 25, 311-325 (2008).

195. Iragavarapu, T. K. \& Randall, G. W. Yield and nitrogen uptake of monocropped maize from a long-term tillage experiment on a poorly drained soil. Soil and Tillage Research 34, 145-156 (1995).

196. Irmak, S., Kukal, M. S., Mohammed, A. T. \& Djaman, K. Disk-till vs. no-till maize evapotranspiration, microclimate, grain yield, production functions and water productivity. Agricultural Water Management 216, 177-195 (2019).

197. Ishaque, W. et al. Short-term effects of tillage and residue management practices on dry matter yield and fate of $15 \mathrm{~N}$-urea in a continuous maize cropping system under subtropical conditions. Soil and Tillage Research 182, 78-85 (2018).

198. Ismail, I., Blevins, R. L. \& Frye, W. W. Long-Term No-tillage Effects on Soil Properties and Continuous Corn Yields. Soil Science Society of America Journal 58, 193-198 (1994).

199. Issaka, F. et al. Zero tillage improves soil properties, reduces nitrogen loss and increases productivity in a rice farmland in Ghana. Agronomy 9, 641 (2019).

200. Izaurralde, R. C., Choudhary, M., Juma, N. G., McGill, W. B. \& Haderlein, L. Crop and nitrogen yield in legume-based rotations practiced with zero tillage and low-input methods. Agronomy Journal 87, 958-964 (1995).

201. Izumi, Y., Uchida, K. \& Iijima, M. Crop production in successive wheat-soybean rotation with no-tillage practice in relation to the root system development. Plant Production Science 7, 329-336 (2004).

202. Jat, M. L. et al. Evaluation of precision land leveling and double zero-till systems in the rice-wheat rotation: Water use, productivity, profitability and soil physical properties. Soil and Tillage Research 105, 112-121 (2009).

203. Jat, R. K. et al. Ten years of conservation agriculture in a rice-maize rotation of Eastern Gangetic Plains of India: Yield trends, water productivity and economic profitability. Field Crops Research 232, 1-10 (2019).

204. Jones, M. J. Comparison of conservation tillage systems in barley-based cropping systems in Northern Syria. Experimental Agriculture 36, 15-26 (2000).

205. Jones, O. R. \& Popham, T. W. Cropping and tillage systems for dryland grain production in the southern high plains. Agronomy Journal 89, 222-232 (1997).

206. Jug, D. et al. Effect of conservation tillage on crop productivity and nitrogen use efficiency. Soil and Tillage Research 194, 104327 (2019). 
207. Kabanza, A. K. \& Rwehumbiza, F. B. R. Assessment of the contribution of tied ridges and farmyard manure application to sorghum production in semi-arid areas of Tanzania. in Advances in Integrated Soil Fertility Management in sub-Saharan Africa: Challenges and Opportunities 723-730 (Springer Netherlands, 2007).

208. Kabir, Z., O'Halloran, I. P., Fyles, J. W. \& Hamel, C. Seasonal changes of arbuscular mycorrhizal fungi as affected by tillage practices and fertilization: Hyphal density and mycorrhizal root colonization. Plant and Soil 192, 285-293 (1997).

209. Kafesu, N. et al. Comparative fertilization effects on maize productivity under conservation and conventional tillage on sandy soils in a smallholder cropping system in Zimbabwe. Field Crops Research 218, 106-114 (2018).

210. Kandel, T. P., Gowda, P. H., Northup, B. K. \& Rocateli, A. C. Impacts of tillage systems, nitrogen fertilizer rates and a legume green manure on light interception and yield of winter wheat. Cogent Food \& Agriculture 5, 1-13 (2019).

211. Kanwar, R. S., Baker, J. L. \& Baker, D. G. Tillage and split N-fertilization effects on subsurface drainage water quality and crop yields. Transactions of the ASAE 31, 0453-0461 (1988).

212. Karlen, D. L., Berry, E. C., Colvin, T. S. \& Kanwar, R. S. Twelve-year tillage and crop rotation effects on yields and soil chemical properties in northeast Iowa. Communications in Soil Science and Plant Analysis 22, 1985-2003 (1991).

213. Karlen, D. L., Hunt, P. G. \& Matheny, T. A. Fertilizer 15 nitrogen recovery by corn, wheat, and cotton grown with and without pre-plant tillage on norfolk loamy sand. Crop Science 36, 975-981 (1996).

214. Karlen, D. L., Kovar, J. L., Cambardella, C. A. \& Colvin, T. S. Thirty-year tillage effects on crop yield and soil fertility indicators. Soil and Tillage Research 130, 24-41 (2013).

215. Karunatilake, U., van Es, H. M. \& Schindelbeck, R. R. Soil and maize response to plow and no-tillage after alfalfa-to-maize conversion on a clay loam soil in New York. Soil and Tillage Research 55, 31-42 (2000).

216. Kennedy, C. W. \& Hutchinson, R. L. Cotton growth and development under different tillage systems. Crop Science 41, 1162-1168 (2001).

217. Kihara, J., Bationo, A., Mugendi, D. N., Martius, C. \& Vlek, P. L. G. Conservation tillage, local organic resources and nitrogen fertilizer combinations affect maize productivity, soil structure and nutrient balances in semi-arid Kenya. Nutrient Cycling in Agroecosystems 90, 213-225 (2011).

218. Kisić, I., Bašić, F., Birkas, M., Jurišić, A. \& Bićanić, V. Crop yield and plant density under different tillage systems. Agriculturae Conspectus Scientificus 75, 1-7 (2010).

219. Kitonyo, O. M., Sadras, V. O., Zhou, Y. \& Denton, M. D. Nitrogen fertilization modifies maize yield response to tillage and stubble in a sub-humid tropical environment. Field Crops Research 223, 113-124 (2018).

220. Kladivko, E. J., Griffith, D. R. \& Mannering, J. V. Conservation tillage effects on soil properties and yield of corn and soya beans in Indiana. Soil and Tillage Research 8, 277-287 (1986).

221. Knight, C. W. \& Lewis, C. E. Conservation tillage in the Subarctic. Soil and Tillage Research 7, 341-353 (1986).

222. Kobayashi, H., Miura, S. \& Oyanagi, A. Effects of winter barley as a cover crop on the weed vegetation in a no-tillage soybean. Weed Biology and Management 4, 195-205 (2004).

223. Korucu, T. \& Merdun, H. Effects of tillage systems on wheat yield and residue in Turkey. Journal of Animal and Veterinary Advances 8, 1973-1978 (2009).

224. Kumudini, S., Grabau, L., Van Sanford, D. \& Omielan, J. Analysis of yield-formation processes under no-till and conventional tillage for soft red winter wheat in the south-central region. Agronomy Journal 100, 1026-1032 (2008).

225. Kurle, J. E., Grau, C. R., Oplinger, E. S. \& Mengistu, A. Tillage, crop sequence, and cultivar effects on sclerotinia stem rot incidence and yield in soybean. Agronomy Journal 93, 973-982 (2001).

226. Kushwaha, C. P. \& Singh, K. P. Crop productivity and soil fertility in a tropical dryland agro-ecosystem: impact of residue and tillage management. Experimental Agriculture 41, 39-50 (2005).

227. Kutcher, H. R., Johnston, A. M., Bailey, K. L. \& Malhi, S. S. Managing crop losses from plant diseases with foliar fungicides, rotation and tillage on a Black Chernozem in Saskatchewan, Canada. Field Crops Research 124, 205-212 (2011).

228. Lafond, G. P., May, W. E., Stevenson, F. C. \& Derksen, D. A. Effects of tillage systems and rotations on crop production for a thin Black Chernozem in the Canadian Prairies. Soil and Tillage Research 89, 232-245 (2006).

229. Lal, R. Soil degradative effects of slope length and tillage methods on alfisols in western Nigeria. I. Runoff, erosion and crop response. Land Degradation \& Development 8, 201-219 (1997).

230. Lal, R. Axle load and tillage effects on crop yields on a Mollic Ochraqualf in Northwest Ohio. Soil and Tillage Research 37, 143-160 (1996).

231. Lal, R. Long-term tillage and maize monoculture effects on a tropical Alfisol in western Nigeria. I. Crop yield and soil physical properties. Soil and Tillage Research 42, 145-160 (1997).

232. Lal, R. \& Ahmadi, M. Axle load and tillage effects on crop yield for two soils in central Ohio. Soil and Tillage Research 54, 111-119 (2000).

233. Lal, R., Logan, T. J. \& Fausey, N. R. Long-term tillage and wheel traffic effects on a poorly drained mollic ochraqualf in northwest Ohio. 1. Soil physical properties, root distribution and grain yield of corn and soybean. Soil and Tillage Research 14, 341-358 (1989).

234. Lampurlanés, J., Angás, P. \& Cantero-Martínez, C. Root growth, soil water content and yield of barley under different tillage systems on two soils in semiarid conditions. Field Crops Research 69, 27-40 (2001).

235. Landschoot, S. et al. Does shifting from conventional to zero tillage in combination with a cover crop offers opportunities for silage maize cultivation in Flanders? Journal of Plant Nutrition and Soil Science 182, 980-989 (2019).

236. Latifmanesh, H. et al. Integrative impacts of rotational tillage on wheat yield and dry matter accumulation under corn-wheat cropping system. Soil and Tillage Research 184, 100-108 (2018).

237. Latta, J. \& O'Leary, G. J. Long-term comparison of rotation and fallow tillage systems of wheat in Australia. Field Crops Research 83, 173-190 (2003).

238. Lawrance, K. F., Prinsloo, M. A. \& Berry, W. A. J. Long and short term effects of tillage systems on grain yield, the incidence of diseases and production costs for maize. South African Journal of Plant and Soil 16, 85-91 (1999).

239. Lenssen, A. W., Sainju, U. M., Allen, B. L., Jabro, J. D. \& Stevens, W. B. Dryland corn production and water use affected by tillage and crop management intensity. Agronomy Journal 110, 2439-2446 (2018).

240. Li, Y. \& Ming, H. Effects of tillage managements on soil rapidly available nutrient content and the yield of winter wheat in west Henan province, China. Procedia Environmental Sciences 11, 843-849 (2011).

241. Li, Z. et al. In search of long-term sustainable tillage and straw mulching practices for a maize-winter wheat-soybean rotation system in the Loess Plateau of China. Field Crops Research 217, 199-210 (2018).

242. Licht, M. A. \& Al-Kaisi, M. Corn response, nitrogen uptake, and water use in strip-tillage compared with no-tillage and chisel plow. Agronomy Journal 97, 705-710 (2005).

243. Linden, D. R., Clapp, C. E. \& Dowdy, R. H. Long-term corn grain and stover yields as a function of tillage and residue removal in east central Minnesota. Soil and Tillage Research 56, 167-174 (2000).

244. Lithourgidis, A. S., Tsatsarelis, C. A. \& Dhima, K. V. Tillage effects on corn emergence, silage yield, and labor and fuel inputs in double cropping with wheat. Crop Science 45, 2523-2528 (2005).

245. Liu, J., Fan, Y., Ma, Y. \& Li, Q. Response of photosynthetic active radiation interception, dry matter accumulation, and grain yield to tillage in two winter wheat genotypes. Archives of Agronomy and Soil Science 1-12 (2019). 
246. Liu, T., Huang, J., Chai, K., Cao, C. \& Li, C. Effects of N fertilizer sources and tillage practices on NH3 volatilization, grain yield, and $\mathrm{N}$ use efficiency of rice fields in Central China. Frontiers in Plant Science 9, 1-10 (2018).

247. Liu, Z. et al. Soil organic carbon increment sources and crop yields under long-term conservation tillage practices in wheat-maize systems. Land Degradation \& Development (2020).

248. López, M. V. \& Arrúe, J. L. Growth, yield and water use efficiency of winter barley in response to conservation tillage in a semi-arid region of Spain. Soil and Tillage Research 44, 35-54 (1997).

249. López-Bellido, L., Fuentes, M., Castillo, J. E., López-Garrido, F. J. \& Fernández, E. J. Long-term tillage, crop rotation, and nitrogen fertilizer effects on wheat yield under rainfed Mediterranean conditions. Agronomy Journal 88, 783-791 (1996).

250. López-Bellido, L., López-Bellido, R., Castillo, J. \& López-Bellido, F. Chickpea response to tillage and soil residual nitrogen in a continuous rotation with wheat. Field Crops Research 88, 191-200 (2004).

251. López-Bellido, L. et al. Wheat response to nitrogen splitting applied to a Vertisols in different tillage systems and cropping rotations under typical Mediterranean climatic conditions. European Journal of Agronomy 43, 24-32 (2012).

252. López-Vázquez, A., Cadena-Zapata, M., Campos-Magaña, S., Zermeño-Gonzalez, A. \& Mendez-Dorado, M. Comparison of energy used and effects on bulk density and yield by tillage systems in a semiarid condition of Mexico. Agronomy 9, 189 (2019).

253. Lötjönen, T. \& Isolahti, M. Direct drilling of cereals after ley and slurry spreading. Acta Agriculturae Scandinavica Section B: Soil and Plant Science 60, 307-319 (2010).

254. Lowery, B. Groundwater quality and crop-yield responses to tillage management on a Sparta sand. Soil and Tillage Research 48, 225-237 (1998).

255. Lv, S. H. et al. An opportunity for regenerative rice production: Combining plastic film cover and plant biomass mulch with no-till soil management to build soil carbon, curb nitrogen pollution, and maintain high-stable yield. Agronomy 9, 1-22 (2019).

256. Ma, Y. et al. Mitigation of nitrous oxide emissions from paddy soil under conventional and no-till practices using nitrification inhibitors during the winter wheat-growing season. Biology and Fertility of Soils 49, 627-635 (2013).

257. Maali, S. H. \& Agenbag, G. A. Effect of soil tillage, crop rotation and nitrogen application rates on grain yield of spring wheat (Triticum aestivum L.) in the Swartland wheat producing area of the Republic of South Africa. South African Journal of Plant and Soil 20, 111-118 (2003).

258. Machado, S., Petrie, S., Rhinhart, K. \& Qu, A. Long-term continuous cropping in the Pacific Northwest: Tillage and fertilizer effects on winter wheat, spring wheat, and spring barley production. Soil and Tillage Research 94, 473-481 (2007).

259. Mahata, K. R., Sen, H. S., Pradhan, S. K. \& Mandal, L. N. No-tillage and dry ploughing compared with puddling for wet-season rice on an alluvial sandy clay-loam in eastern India. The Journal of Agricultural Science 114, 79-86 (1990).

260. Małecka, I., Blecharczyk, A., Sawinska, Z. \& Dobrzeniecki, T. The effect of various long-term tillage systems on soil properties and spring barley yield. Turkish Journal of Agriculture and Forestry 36, 217-226 (2012).

261. Malhi, S. S. \& Lemke, R. Tillage, crop residue and N fertilizer effects on crop yield, nutrient uptake, soil quality and nitrous oxide gas emissions in a second 4-yr rotation cycle. Soil and Tillage Research 96, 269-283 (2007).

262. Malhi, S. S., Lemke, R., Wang, Z. H. \& Chhabra, B. S. Tillage, nitrogen and crop residue effects on crop yield, nutrient uptake, soil quality, and greenhouse gas emissions. Soil and Tillage Research 90, 171-183 (2006).

263. Malhi, S. S., McAndrew, D. W. \& Carter, M. R. Effect of tillage and N fertilization of a Solonetzic soil on barley production and some soil properties. Soil and Tillage Research 22, 95-107 (1992).

264. Martínez, E., Fuentes, J.-P., Pino, V., Silva, P. \& Acevedo, E. Chemical and biological properties as affected by no-tillage and conventional tillage systems in an irrigated Haploxeroll of Central Chile. Soil and Tillage Research 126, 238-245 (2013).

265. Martin-Rueda, I. et al. Tillage and crop rotation effects on barley yield and soil nutrients on a Calciortidic Haploxeralf. Soil and Tillage Research 92, 1-9 (2007).

266. Maurya, P. R. Effect of tillage and residue management of maize and wheat yield and on physical properties of an irrigated sandy loam soil in Northern Nigeria. Soil and Tillage Research 8, 161-170 (1986).

267. McAndrew, D. W., Fuller, L. G. \& Wetter, L. G. Grain and straw yields of barley under four tillage systems in northeastern Alberta. Canadian Journal of Plant Science 74, 713-722 (1994).

268. McConkey, B. G., Campbell, C. A., Zentner, R. P., Dyck, F. B. \& Selles, F. Long-term tillage effects on spring wheat production on three soil textures in the brown soil zone. Canadian Journal of Plant Science 76, 747-756 (1996).

269. McConkey, B. G., Ulrich, D. J. \& Dyck, F. B. Snow management and deep tillage for increasing crop yields on a rolling landscape. Canadian Journal of Soil Science 77, 479-486 (1997).

270. Melero, S. et al. Long-term effect of tillage, rotation and nitrogen fertiliser on soil quality in a Mediterranean Vertisol. Soil and Tillage Research 114, 97-107 (2011).

271. Messiga, A. J. et al. Long term impact of tillage practices and biennial $\mathrm{P}$ and $\mathrm{N}$ fertilization on maize and soybean yields and soil $\mathrm{P}$ status. Field Crops Research 133, 10-22 (2012).

272. Mishra, J. S. \& Singh, V. P. Tillage and weed control effects on productivity of a dry seeded rice-wheat system on a Vertisol in Central India. Soil and Tillage Research 123, 11-20 (2012).

273. Mitra, B. et al. Nutrient management in wheat (Triticum aestivum) production system under conventional and zero tillage in eastern sub-Himalayan plains of India. Indian Journal of Agricultural Sciences 89, 775-784 (2019).

274. Monneveux, P., Quillérou, E., Sanchez, C. \& Lopez-Cesati, J. Effect of zero tillage and residues conservation on continuous maize cropping in a subtropical environment (Mexico). Plant and Soil 279, 95-105 (2006).

275. Morell, F. J., Lampurlanés, J., Álvaro-Fuentes, J. \& Cantero-Martínez, C. Yield and water use efficiency of barley in a semiarid Mediterranean agroecosystem: Long-term effects of tillage and N fertilization. Soil and Tillage Research 117, 76-84 (2011).

276. Moret, D., Arrúe, J. L., López, M. V. \& Gracia, R. Winter barley performance under different cropping and tillage systems in semiarid Aragon (NE Spain). European Journal of Agronomy 26, 54-63 (2007).

277. Morrison, M. J. et al. Tillage and crop rotation effects on the yield of corn, soybean and wheat in eastern Canada. Canadian Journal of Plant Science 98, 183-191 (2017).

278. Mosier, A. R., Halvorson, A. D., Reule, C. A. \& Liu, X. J. Net global warming potential and greenhouse gas intensity in irrigated cropping systems in Northeastern Colorado. Journal of Environmental Quality 35, 1584-1598 (2006)

279. Mrabet, R. Differential response of wheat to tillage management systems in a semiarid area of Morocco. Field Crops Research 66, $165-174(2000)$.

280. Mtyobile, M., Muzangwa, L. \& Mnkeni, P. N. S. Tillage and crop rotation effects on selected soil chemical properties and wheat yield in a sandy loam oakleaf soil in the Eastern Cape, South Africa. International Journal of Agriculture and Biology 21, 367-374 (2019).

281. Mulugeta, D. \& Stoltenberg, D. E. Weed and seedbank management with integrated methods as influenced by tillage. Weed Science 45, 706-715 (1997).

282. Mutsamba, E. F., Nyagumbo, I. \& Mupangwa, W. Forage and maize yields in mixed crop-livestock farming systems: Enhancing forage and maize yields in $\mathrm{mi}$

283. Nandan, R. et al. Crop establishment with conservation tillage and crop residue retention in rice-based cropping systems of Eastern India: yield advantage and economic benefit. Paddy and Water Environment 16, 477-492 (2018).

284. Narayan, D., Tiwari, A. K., Lal, B. \& Katiyar, V. S. Effect of tillage practices and cover management on soil and water conservation and yield of sorghum. Annals of Arid Zone 48, 133-138 (2009). 
285. Nazirah, L., Purba, E., Hanum, C. \& Rauf, A. Effect of soil tillage and mycorrhiza application on growth and yields of upland rice in drought condition. Asian Journal of Agriculture and Biology 6, 251-258 (2018).

286. Ndoli, A. et al. Conservation agriculture with trees amplifies negative effects of reduced tillage on maize performance in East Africa. Field Crops Research 221, 238-244 (2018).

287. Newton, A. C. et al. Soil tillage effects on the efficacy of cultivars and their mixtures in winter barley. Field Crops Research 128, 91-100 (2012).

288. Ngwira, A. R., Aune, J. B. \& Mkwinda, S. On-farm evaluation of yield and economic benefit of short term maize legume intercropping systems under conservation agriculture in Malawi. Field Crops Research 132, 149-157 (2012).

289. Ngwira, A. R., Kabambe, V., Simwaka, P., Makoko, K. \& Kamoyo, K. Productivity and profitability of maize-legume cropping systems under conservation agriculture among smallholder farmers in Malawi. Acta Agriculturae Scandinavica, Section B - Soil \& Plant Science 70, 241-251 (2020).

290. Nielsen, D. C. et al. Cropping system influence on planting water content and yield of winter wheat. Agronomy Journal 94, 962-967 (2002).

291. Noel, G. R. \& Wax, L. M. Population dynamics of Heterodera glycines in conventional tillage and no-tillage soybean/corn cropping systems. Journal of Nematology 35, 104-109 (2003).

292. Norwood, C. Profile water distribution and grain yield as affected by cropping system and tillage. Agronomy Journal 86, 558-563 (1994).

293. Norwood, C. A. Water use and yield of dryland row crops as affected by tillage. Agronomy Journal 91, 108-115 (1999).

294. Norwood, C. A. \& Currie, R. S. Tillage, planting date, and plant population effects on dryland corn. Journal of Production Agriculture 9, 119-122 (1996).

295. Nouri, A. et al. Soil physical properties and soybean yield as influenced by long-term tillage systems and cover cropping in the Midsouth USA. Sustainability (Switzerland) 10 (2018).

296. Nyamadzawo, G., Nyamugafata, P., Wuta, M. \& Nyamangara, J. Maize yields under coppicing and non coppicing fallows in a fallow-maize rotation system in central Zimbabwe. Agroforestry Systems 84, 273-286 (2012).

297. Nyborg, M., Solberg, E. D., Izaurralde, R. C., Malhi, S. S. \& Molina-Ayala, M. Influence of long-term tillage, straw and N fertilizer on barley yield, plant-N uptake and soil-N balance. Soil and Tillage Research 36, 165-174 (1995).

298. Ogunremi, L. T., Lal, R. \& Babalola, O. Effects of tillage and seeding methods on soil physical properties and yield of upland rice for an ultisol in southeast Nigeria. Soil and Tillage Research 6, 305-324 (1986).

299. Ogunremi, L. T., Lal, R. \& Babalola, O. Effects of tillage methods and water regimes on soil properties and yield of lowland rice from a sandy loam soil in Southwest Nigeria. Soil and Tillage Research 6, 223-234 (1986).

300. Ojeniyi, S. O. Nutrient availability and maize yield under reduced tillage practices. Soil and Tillage Research 26, 89-92 (1993).

301. Olson, K. R., Ebelhar, S. A. \& Lang, J. M. Effects of 24 years of conservation tillage systems on soil organic carbon and soil productivity. Applied and Environmental Soil Science 2013 (2013).

302. Opoku, G., Vyn, T. J. \& Swanton, C. J. Modified no-till systems for corn following wheat on clay softs. Agronomy Journal 89, 549-556 (1997).

303. Osuji, G. E. Water storage, water use and maize yield for tillage systems on a tropical alfisol in Nigeria. Soil and Tillage Research 4, 339-348 (1984).

304. Ouédraogo, E., Mando, A., Brussaard, L. \& Stroosnijder, L. Tillage and fertility management effects on soil organic matter and sorghum yield in semi-arid West Africa. Soil and Tillage Research 94, 64-74 (2007).

305. Pabin, J., Lipiec, J., Włodek, S. \& Biskupski, A. Maize response to different straw management and tillage systems under cereal crop rotation. International Agrophysics 20, 141-146 (2006).

306. Pagnani, G. et al. Effect of soil tillage and crop sequence on grain yield and quality of durum wheat in Mediterranean areas. Agronomy 9, 488 (2019).

307. Pala, M., Harris, H. C., Ryan, J., Makboul, R. \& Dozom, S. Tillage systems and stubble management in a Mediterranean-type environment in relation to crop yield and soil moisture. Experimental Agriculture 36, 223-242 (2000).

308. Pareja-Sánchez, E., Plaza-Bonilla, D., Álvaro-Fuentes, J. \& Cantero-Martínez, C. Is it feasible to reduce tillage and N use while improving maize yield in irrigated Mediterranean agroecosystems? European Journal of Agronomy 109, 125919 (2019).

309. Parihar, C. M. et al. Effects of precision conservation agriculture in a maize-wheat-mungbean rotation on crop yield, water-use and radiation conversion under a semiarid agro-ecosystem. Agricultural Water Management 192, 306-319 (2017).

310. Parihar, C. M. et al. Soil water dynamics, water productivity and radiation use efficiency of maize under multi-year conservation agriculture during contrasting rainfall events. Field Crops Research 241, 107570 (2019).

311. Parihar, C. M. et al. Conservation agriculture in irrigated intensive maize-based systems of north-western India: Effects on crop yields, water productivity and economic profitability. Field Crops Research 193, 104-116 (2016).

312. Parihar, M. D. et al. Effect of different tillage and residue management practices on crop and water productivity and economics in maize (Zea mays) based rotations. Indian Journal of Agricultural Sciences 89, 360-366 (2019).

313. Parkin, T. B. \& Kaspar, T. C. Nitrous Oxide Emissions from Corn-Soybean Systems in the Midwest. Journal of Environmental Quality 35, 1496-1506 (2006).

314. Peachey, B. E., William, R. D. \& Mallory-smith, C. Effect of spring tillage sequence on summer annual weeds in vegetable row crop rotations. Weed Technology 20, 204-214 (2018).

315. Pearce, A. D., Dillon, C. R., Keisling, T. C. \& Wilson, C. E. Economic and agronomic effects of four tillage practices on rice produced on saline soils. Journal of Production Agriculture 12, 305-312 (1999).

316. Pelster, D. E. et al. Nitrogen fertilization but not soil tillage affects nitrous oxide emissions from a clay loam soil under a maize-soybean rotation. Soil and Tillage Research 115-116, 16-26 (2011).

317. Peng, Z. et al. Conservation tillage increases water use efficiency of spring wheat by optimizing water transfer in a semi-arid environment. Agronomy 9, 583 (2019).

318. Perego, A. et al. Agro-environmental aspects of conservation agriculture compared to conventional systems: A 3-year experience on 20 farms in the Po valley (Northern Italy). Agricultural Systems 168, 73-87 (2019).

319. Pettigrew, W. T. \& Jones, M. A. Cotton growth under no-till production in the lower Mississippi river valley alluvial flood plain. Agronomy Journal 93, 1398-1404 (2001).

320. Plaza-Bonilla, D. et al. No-tillage reduces long-term yield-scaled soil nitrous oxide emissions in rainfed Mediterranean agroecosystems: A field and modelling approach. Agriculture, Ecosystems and Environment 262, 36-47 (2018).

321. Potter, K. N., Morrison, J. E. \& Torbert, H. A. Tillage intensity effects on corn and grain sorghum growth and productivity on a vertisol. Journal of Production Agriculture 9, 385-390 (1996).

322. Pradhan, P. R. et al. Tillage and crop residue management practices on crop productivity, phosphorus uptake and forms in wheat (Triticum aestivum)-based cropping systems. Indian Journal of Agricultural Sciences 81, 1168-1173 (2011).

323. Qin, J. et al. The effect of mulching, tillage and rotation on yield in non-flooded compared with flooded rice production. Journal of Agronomy and Crop Science 196, 397-406 (2010).

324. Quincke, J. A. et al. One-time tillage of no-till systems: soil physical properties, phosphorus runoff, and crop yield. Agronomy Journal 99, 1104-1110 (2007).

325. Radford, B. J. \& Thornton, C. M. Effects of 27 years of reduced tillage practices on soil properties and crop performance in the semi-arid subtropics of Australia. The International Journal of Electrical Engineering \& Education 19, 565 (2011). 
326. Ram, H., Kler, D. S., Singh, Y. \& Kumar, K. Productivity of maize (Zea mays) - wheat (Triticum aestivum) system under different tillage and crop establishment practices. Indian Journal of Agronomy 55, 185-190 (2010).

327. Ram, H., Kumar, K., Kler, D. S. \& Singh, Y. Effect of permanent bed planting and tillage options on microenvironment, crop productivity, water use efficiency, and soil properties under soybean (Glycine max L.) - wheat (Triticum aestivum L.) cropping system. Ecology, Environment and Conservation 16, 593-599 (2010).

328. Ramos, M. C., Pareja-Sánchez, E., Plaza-Bonilla, D., Cantero-Martínez, C. \& Lampurlanés, J. Soil sealing and soil water content under no-tillage and conventional tillage in irrigated corn: Effects on grain yield. Hydrological Processes 33, 2095-2109 (2019).

329. Rao, S. C. \& Dao, T. H. Nitrogen placement and tillage effects on dry matter and nitrogen accumulation and redistribution in winter wheat. Agronomy Journal 88, 365-371 (1996).

330. Rashid, M. H., Timsina, J., Islam, N. \& Islam, S. Tillage and residue-management effects on productivity, profitability and soil properties in a rice-maize-mungbean system in the Eastern Gangetic Plains. Journal of Crop Improvement 33, 683-710 (2019).

331. Rasmussen, P. E. \& Douglas, C. L. The influence of tillage and cropping-intensity on cereal response to nitrogen, sulfur, and phosphorus. Fertilizer Research 31, 15-19 (1992).

332. Rasse, D. P. \& Smucker, A. J. M. Tillage effects on soil nitrogen and plant biomass in a corn-alfalfa rotation. Journal of Environmental Quality 28, 873-880 (1999).

333. Reddy, C. K., Nyakatawa, E. Z. \& Reeves, D. W. Tillage and poultry litter application effects on cotton growth and yield. Agronomy Journal 96, 1641-1650 (2004).

334. Reddy, S. S. et al. Long-term effects of poultry litter and conservation tillage on crop yields and soil phosphorus in cotton-cotton-corn rotation. Field Crops Research 114, 311-319 (2009).

335. Reddy, S. S., Nyakatawa, E. Z. \& Reddy, C. K. Nitrogen uptake pattern by cotton in a long-term no-tillage system with poultry litter application. International Journal of Agriculture and Biology 14,29-37 (2012).

336. Rembon, F. S. \& MacKenzie, A. F. Soybean nitrogen contribution to corn and residual nitrate under conventional tillage and no-till. Canadian Journal of Soil Science 77, 543-551 (1997).

337. Ren, Y., Gao, C., Han, H. \& Li, Q. Response of water use efficiency and carbon emission to no-tillage and winter wheat genotypes in the North China Plain. Science of The Total Environment 635, 1102-1109 (2018).

338. Renner, K. A., Schabenberger, O. \& Kells, J. J. Effect of tillage and application method on corn (Zea mays) response to imidazolinone residues in soil. Weed Technology 12, 281-285 (1998)

339. Ribera, L. A., Hons, F. M. \& Richardson, J. W. An economic comparison between conventional and no-tillage farming systems in Burleson County, Texas. Agronomy Journal 96, 415-424 (2004).

340. Rochette, P., Angers, D. A., Chantigny, M. H. \& Bertrand, N. Nitrous oxide emissions respond differently to no-till in a loam and a heavy clay soil. Soil Science Society of America Journal 72, 1363-1369 (2008).

341. Roper, M. M., Ward, P. R., Keulen, A. F. \& Hill, J. R. Under no-tillage and stubble retention, soil water content and crop growth are poorly related to soil water repellency. Soil and Tillage Research 126, 143-150 (2013).

342. Rozas, H. S., Echeverria, H. E., Studdert, G. A. \& Dominguez, G. Evaluation of the presidedress soil nitrogen test for no-tillage maize fertilized at planting. Agronomy Journal 92, 1176-1183 (2000)

343. Saha, S. et al. Effect of tillage and residue management on soil physical properties and crop productivity in maize (Zea mays)Indian mustard (Brassica juncea) system. Indian Journal of Agricultural Sciences 80, 679-685 (2010).

344. Saharawat, Y. S. et al. Evaluation of alternative tillage and crop establishment methods in a rice-wheat rotation in North Western IGP. Field Crops Research 116, 260-267 (2010).

345. Sainju, U. M. \& Singh, B. P. Tillage, cover crop, and kill-planting date effects on corn yield and soil nitrogen. Agronomy Journal 93, 878-886 (2001).

346. Sainju, U. M., Whitehead, W. F., Singh, B. P. \& Wang, S. Tillage, cover crops, and nitrogen fertilization effects on soil nitrogen and cotton and sorghum yields. European Journal of Agronomy 25, 372-382 (2006).

347. Sainju, U. M., Lenssen, A. W., Caesar-TonThat, T. \& Evans, R. G. Dryland crop yields and soil organic matter as influenced by longterm tillage and cropping sequence. Agronomy Journal 101, 243-251 (2009).

348. Schillinger, W. F., Cook, R. J. \& Papendick, R. I. Increased dryland cropping intensity with no-till barley. Agronomy Journal 91, 744-752 (1999).

349. Schlegel, A. J., Dhuyvetter, K. C., Thompson, C. R. \& Havlin, J. L. Agronomic and economic impacts of tillage and rotation on wheat and sorghum. Journal of Production Agriculture 12, 629-636 (1999).

350. Schlegel, A. J., Assefa, Y., Haag, L. A., Thompson, C. R. \& Stone, L. R. Long-term tillage on yield and water use of grain sorghum and winter wheat. Agronomy Journal 110, 269-280 (2018).

351. Schwab, G. J., Whitney, D. A., Kilgore, G. L. \& Sweeney, D. W. Tillage and phosphorus management effects on crop production in soils with phosphorus stratification. Agronomy Journal 98, 430-435 (2006).

352. Selles, F., McConkey, B. G. \& Campbell, C. A. Distribution and forms of P under cultivator- and zero-tillage for continuous- and fallow-wheat cropping systems in the semi-arid Canadian prairies. Soil and Tillage Research 51, 47-59 (1999).

353. Sepat, S., Bana, R. S., Meena, S. L. \& Rana, D. S. Assessment of conservation agriculture and intercropping practices for enhanced productivity and profitability in maize (Zea mays). Indian Journal of Agricultural Sciences 89, 714-720 (2019).

354. Sessiz, A., Alp, A. \& Gursoy, S. Conservation and conventional tillage methods on selected soil physical properties and corn (Zea Mays L.) yield and quality under croppin system in Turkey. Bulgarian Journal of Agricultural Science 16, 597-608 (2010).

355. Sessiz, A., Sogut, T., Alp, A. \& Esgici, R. Tillage effects on sunflower (helianthus annuus, 1.) emergence, yield, quality, and fuel consumption in double cropping system. Journal of Central European Agriculture 9, 697-710 (2008).

356. Shapiro, C. A. et al. Tillage and management alternatives for returning conservation reserve program land to crops. Agronomy Journal 93, 850-862 (2001).

357. Sharma, P. K., de Datta, S. K. \& Redulla, C. A. Response of maize (Zea mays L.) and mungbean (Vigna radiata L.) to tillage in relation to water table depth in tropical lowland rice soils. Soil and Tillage Research 12, 65-79 (1988).

358. Sharma, R. K., Babu, S., Chhokar, K. \& Sharma, R. S. A. K. Effect of tillage on termites, weed incidence and productivity of spring wheat in rice-wheat system of North Western Indian plains. Crop Protection 23, 1049-1054 (2004).

359. Sharratt, B. Barley yield and evapotranspiration governed by tillage practices in interior Alaska. Soil and Tillage Research 46, 225-229 (1998)

360. Si, P. et al. Effect of no-tillage with straw mulch and conventional tillage on soil organic carbon pools in Northern China. Archives of Agronomy and Soil Science 64, 398-408 (2018).

361. Sidhu, D. \& Duiker, S. W. Soil compaction in conservation tillage: crop impacts. Agronomy Journal 98, 1257-1264 (2006).

362. Silva, F. A. M., Naudin, K., Corbeels, M., Scopel, E. \& Affholder, F. Impact of conservation agriculture on the agronomic and environmental performances of maize cropping under contrasting climatic conditions of the Brazilian Cerrado. Field Crops Research 230, 72-83 (2019).

363. Silva, P., Garrido, M., Shertzer, G. \& Acevedo, E. Amount of rain until third leaf explain differences in irrigated durum wheat yield between a conventional and no-tillage system in a long-term crop rotation system in Mediterranean environment. International Journal of Plant Production 13, 339-346 (2019).

364. Simón, M. R. et al. Integrated foliar disease management to prevent yield loss in Argentinian wheat production. Agronomy Journal 103, 1441-1451 (2011). 
365. Singer, J. W. et al. Tillage and compost affect yield of corn, soybean, and wheat and soil fertility. Agronomy Journal 96, 531-537 (2004).

366. Singer, J. W., Logsdon, S. D. \& Meek, D. W. Soybean growth and seed yield response to tillage and compost. Agronomy Journal 100, 1039-1046 (2008)

367. Singer, J. W., Logsdon, S. D. \& Meek, D. W. Tillage and compost effects on corn growth, nutrient accumulation, and grain yield. Agronomy Journal 99, 80-87 (2007).

368. Singh, V., Ram, S., Bhatnagar, A. \& Savita, U. Effect of tillage methods on soil properties and productivity of quality protein maize (Zea mays)-wheat (Triticum aestivum) system. Indian Journal of Agronomy 56, 83-87 (2011).

369. Singh, V. K. et al. Soil physical properties, yield trends and economics after five years of conservation agriculture based rice-maize system in north-western India. Soil and Tillage Research 155, 133-148 (2016).

370. Sistani, K. R., Sikora, F. J. \& Rasnake, M. Poultry litter and tillage influences on corn production and soil nutrients in a Kentucky silt loam soil. Soil and Tillage Research 98, 130-139 (2008).

371. Sistani, K. R. et al. Nutrient source and tillage impact on corn grain yield and soil properties. Soil Science 175, 593-600 (2010).

372. Sithole, N. J. \& Magwaza, L. S. Long-term changes of soil chemical characteristics and maize yield in no-till conservation agriculture in a semi-arid environment of South Africa. Soil and Tillage Research 194, 104317 (2019).

373. Smith, D. R., Hernandez-Ramirez, G., Armstrong, S. D., Bucholtz, D. L. \& Stott, D. E. Fertilizer and tillage management impacts on non-carbon-dioxide greenhouse gas emissions. Soil Science Society of America Journal 75, 1070-1082 (2011).

374. So, H. B., Grabski, A. \& Desborough, P. The impact of 14 years of conventional and no-till cultivation on the physical properties and crop yields of a loam soil at Grafton NSW, Australia. Soil and Tillage Research 104, 180-184 (2009).

375. Soane, B. D. \& Ball, B. C. Review of management and conduct of long-term tillage studies with special reference to a $25-\mathrm{yr}$ experiment on barley in Scotland. Soil and Tillage Research 45, 17-37 (1998).

376. Song, K. et al. Effects of tillage and straw return on water-stable aggregates, carbon stabilization and crop yield in an estuarine alluvial soil. Scientific Reports 9, 1-11 (2019).

377. Soon, Y. K. \& Arshad, M. A. Tillage, crop residue and crop sequence effects on nitrogen availability in a legume-based cropping system. Canadian Journal of Soil Science 84, 421-430 (2004).

378. Soon, Y. K., Malhi, S. S., Lemke, R. L., Lupwayi, N. Z. \& Grant, C. A. Effect of polymer-coated urea and tillage on the dynamics of available $\mathrm{N}$ and nitrous oxide emission from Gray Luvisols. Nutrient Cycling in Agroecosystems 90, 267-279 (2011).

379. Sow, A. A., Hossner, L. R., Unger, P. W. \& Stewart, B. A. Tillage and residue effects on root growth and yields of grain sorghum following wheat. Soil and Tillage Research 44, 121-129 (1997).

380. Spargo, J. T., Cavigelli, M. A., Mirsky, S. B., Maul, J. E. \& Meisinger, J. J. Mineralizable soil nitrogen and labile soil organic matter in diverse long-term cropping systems. Nutrient Cycling in Agroecosystems 90, 253-266 (2011).

381. Stecker, J. A., Buchholz, D. D., Hanson, R. G., Wollenhaupt, N. C. \& McVay, K. A. Tillage and rotation effects on corn yield response to fertilizer nitrogen on aqualf soils. Agronomy Journal 87, 409-415 (1995).

382. Steward, P. R., Thierfelder, C., Dougill, A. J. \& Ligowe, I. Conservation agriculture enhances resistance of maize to climate stress in a Malawian medium-term trial. Agriculture, Ecosystems and Environment 277, 95-104 (2019).

383. Stinner, B. R., Odum, E. P. \& Crossley, D. A. Nutrient uptake by vegetation in relation to other ecosystem processes in conventional tillage, no-tillage and old-field systems. Agriculture, Ecosystems and Environment 10, 1-13 (1983).

384. Su, Z. et al. Effects of conservation tillage practices on winter wheat water-use efficiency and crop yield on the Loess Plateau, China. Agricultural Water Management 87, 307-314 (2007).

385. Sulek, A., Wyzinska, M. \& Cacak-Pietrzak, G. Impact of tillage on yield and quality traits of grains of spring wheat cultivars. Engineering for Rural Development 18, 600-606 (2019).

386. Sun, L. et al. Reasonable fertilization improves the conservation tillage benefit for soil water use and yield of rain-fed winter wheat: A case study from the Loess Plateau, China. Field Crops Research 242, 107589 (2019).

387. Sun, L. et al. Conservation agriculture based on crop rotation and tillage in the semi-arid Loess Plateau, China: Effects on crop yield and soil water use. Agriculture, Ecosystems \& Environment 251, 67-77 (2018).

388. Sun, M. et al. Long-term evaluation of tillage methods in fallow season for soil water storage, wheat yield and water use efficiency in semiarid southeast of the Loess Plateau. Field Crops Research 218, 24-32 (2018).

389. Susha, V. S. et al. Impacts of tillage and herbicide mixture on weed interference, agronomic productivity and profitability of a maize - Wheat system in the North-western Indo-Gangetic Plains. Field Crops Research 219, 180-191 (2018).

390. Taa, A., Tanner, D. \& Bennie, A. T. P. Effects of stubble management, tillage and cropping sequence on wheat production in the south-eastern highlands of Ethiopia. Soil and Tillage Research 76, 69-82 (2004).

391. Tabaglio, V. \& Gavazzi, C. Monoculture maize (Zea mays L.) cropped under conventional tillage, no-tillage and N fertilization:(I) Three year yield performances. Italian Journal of Agronomy 61-68 (2009).

392. Tan, Y., Wu, D., Bol, R., Wu, W. \& Meng, F. Conservation farming practices in winter wheat-summer maize cropping reduce GHG emissions and maintain high yields. Agriculture, Ecosystems \& Environment 272, 266-275 (2019).

393. Tarkalson, D. D., Hergert, G. W. \& Cassman, K. G. Long-term effects of tillage on soil chemical properties and grain yields of a dryland winter wheat-sorghum/corn-fallow rotation in the great plains. Agronomy Journal 98, 26-33 (2006).

394. Teal, R. K. et al. Effect of tillage and anhydrous ammonia application on nitrogen use efficiency of hard red winter wheat. Journal of Sustainable Agriculture 30, 51-67 (2007).

395. Tessier, S., Peru, M., Dyck, F. B., Zentner, F. P. \& Campbell, C. A. Conservation tillage for spring wheat production in semi-arid Saskatchewan. Soil and Tillage Research 18, 73-89 (1990).

396. Therrien, M. C. \& Grant, C. A. Effect of tillage management on yield performance in barley. Canadian Journal of Plant Science 78, 301-303 (1998)

397. Thind, H. S. \& Sharma, S. Yadvinder Singh \& Sidhu, H. S. Rice-wheat productivity and profitability with residue, tillage and green manure management. Nutrient Cycling in Agroecosystems 113, 113-125 (2019).

398. Thomsen, I. K. \& Sørensen, P. Tillage-induced N mineralization and N uptake in winter wheat on a coarse sandy loam. Soil and Tillage Research 89, 58-69 (2006).

399. Tolon-Becerra, A., Tourn, M., Botta, G. F. \& Lastra-Bravo, X. Effects of different tillage regimes on soil compaction, maize (Zea mays L.) seedling emergence and yields in the eastern Argentinean Pampas region. Soil and Tillage Research 117, 184-190 (2011).

400. Tørresen, K. S., Skuterud, R., Weiseth, L., Tandsæther, H. J. \& Haugan Jonsen, S. Plant protection in spring cereal production with reduced tillage. I. Grain yield and weed development. Crop Protection 18, 595-603 (1999).

401. Tsegaye, T. \& Hill, R. L. Wheel traffic placement effects on corn response under no-tillage and conventional tillage. Journal of Production Agriculture 9, 95-101 (1996).

402. Tsuji, H., Yamamoto, H., Matsuo, K. \& Usuki, K. The effects of long-term conservation tillage, crop residues and P fertilizer on soil conditions and responses of summer and winter crops on an Andosol in Japan. Soil and Tillage Research 89, 167-176 (2006).

403. Tueche, J. R. \& Hauser, S. Maize (Zea mays L.) yield and soil physical properties as affected by the previous plantain cropping systems, tillage and nitrogen application. Soil and Tillage Research 115-116, 88-93 (2011).

404. Unger, P. W. Tillage and residue effects on wheat, sorghum, and sunflower grown in rotation. Soil Science Society of America Journal 48, 885-891 (1984).

405. Varner, B. T., Epplin, F. M. \& Strickland, G. L. Economics of no-till versus tilled dryland cotton, grain sorghum, and wheat. Agronomy Journal 103, 1329-1338 (2011). 
406. Varsa, E. C., Chong, S. K., Abolaji, J. O., Farquhar, D. A. \& Olsen, F. J. Effect of deep tillage on soil physical characteristics and corn (Zea mays L.) root growth and production. Soil and Tillage Research 43, 219-228 (1997).

407. Vazquez, L., Myhre, D. L., Gallaher, R. N., Hanlon, E. A. \& Portier, K. M. Soil compaction associated with tillage treatments for soybean. Soil and Tillage Research 13, 35-45 (1989).

408. Venterea, R. T., Maharjan, B. \& Dolan, M. S. Fertilizer source and tillage effects on yield-scaled nitrous oxide emissions in a corn cropping system. Journal of Environmental Quality 40, 1521-1531 (2011).

409. Verch, G., Kächele, H., Höltl, K., Richter, C. \& Fuchs, C. Comparing the profitability of tillage methods in Northeast Germany-A field trial from 2002 to 2005. Soil and Tillage Research 104, 16-21 (2009).

410. Verhulst, N. et al. Conservation agriculture for wheat-based cropping systems under gravity irrigation: Increasing resilience through improved soil quality. Plant and Soil 340, 467-479 (2011).

411. Verhulst, N. et al. The effect of tillage, crop rotation and residue management on maize and wheat growth and development evaluated with an optical sensor. Field Crops Research 120, 58-67 (2011).

412. Verhulst, N. et al. Soil water content, maize yield and its stability as affected by tillage and crop residue management in rainfed semi-arid highlands. Plant and Soil 344, 73-85 (2011).

413. Videnović, Ž., Simić, M., Srdić, J. \& Dumanović, Z. Long term effects of different soil tillage systems on maize (Zea mays L.) yields. Plant, Soil and Environment 57, 186-192 (2011).

414. Vyn, T. J. \& Raimbault, B. A. Evaluation of strip tillage systems for corn production in Ontario. Soil and Tillage Research 23, $163-176(1992)$.

415. Vyn, T. J., Galic, D. M. \& Janovicek, K. J. Corn response to potassium placement in conservation tillage. Soil and Tillage Research 67, 159-169 (2002).

416. Vyn, T. J. \& Janovicek, K. J. Potassium placement and tillage system effects on corn response following long-term no till. Agronomy Journal 93, 487-495 (2001).

417. Wagger, M. G. \& Denton, H. P. Crop and tillage rotations: grain yield, residue cover, and soil water. Soil Science Society of America Journal 56, 1233-1237 (1992).

418. Wang, H., Lemke, R., Goddard, T. \& Sprout, C. Tillage and root heat stress in wheat in central Alberta. Canadian Journal of Soil Science 87, 3-10 (2007).

419. Wang, S. et al. The influence of rotational tillage on soil water storage, water use efficiency and maize yield in semi-arid areas under varied rainfall conditions. Agricultural Water Management 203, 376-384 (2018).

420. Wang, X. et al. Tillage time affects soil hydro-thermal properties, seedling growth and yield of maize (Zea mays L.). Applied Ecology and Environmental Research 16, 6007-6023 (2018).

421. Wang, X. et al. Tillage and crop residue effects on rainfed wheat and maize production in northern China. Field Crops Research 132, 106-116 (2012)

422. Watts, D. B. \& Allen Torbert, H. Long-term tillage and poultry litter impacts on soybean and corn grain yield. Agronomy Journal 103, 1479-1486 (2011).

423. West, T. D., Griffith, D. R. \& Steinhardt, G. C. Effect of paraplowing on crop yields with no-till planting. Journal of Production Agriculture 9, 233-237 (1996).

424. West, T. D., Griffith, D. R., Steinhardt, G. C., Kladivko, E. J. \& Parsons, S. D. Effect of tillage and rotation on agronomic performance of corn and soybean: Twenty-year study on dark silty clay loam soil. Journal of Production Agriculture 9, 241-248 (1996).

425. Whalen, J. K., Prasher, S. O. \& Benslim, H. Monitoring corn and soybean agroecosystems after establishing no-tillage practices in Québec, Canada. Canadian Journal of Plant Science 87, 841-849 (2007).

426. Wiatrak, P. J., Wright, D. L. \& Marois, J. J. The impact of tillage and residual nitrogen on wheat. Soil and Tillage Research 91, 150-156 (2006).

427. Wilhelm, W. W. et al. Dryland maize development and yield resulting from tillage and nitrogen fertilization practices. Soil and Tillage Research 10, 167-179 (1987).

428. Wilhelm, W. W. \& Wortmann, C. S. Tillage and rotation interactions for corn and soybean grain yield as affected by precipitation and air temperature. Agronomy Journal 96, 425-432 (2004).

429. Winter, S. R. \& Unger, P. W. Irrigated wheat grazing and tillage effects on subsequent dryland grain sorghum production. Agronomy Journal 93, 504-510 (2001).

430. Wolkowski, R. P. Row-placed fertilizer for maize grown with an in-row crop residue management system in southern Wisconsin. Soil and Tillage Research 54, 55-62 (2000).

431. Wortmann, C. S., Drijber, R. A. \& Franti, T. G. One-time tillage of no-till crop land five years post-tillage. Agronomy Journal 102, $1302-1307$ (2010)

432. Xu, J., Han, H., Ning, T., Li, Z. \& Lal, R. Long-term effects of tillage and straw management on soil organic carbon, crop yield, and yield stability in a wheat-maize system. Field Crops Research 233, 33-40 (2019).

433. Xu, Y. et al. Agronomic performance of late-season rice under different tillage, straw, and nitrogen management. Field Crops Research 115, 79-84 (2010).

434. Xue, L. et al. Effects of tillage practices on water consumption and grain yield of dryland winter wheat under different precipitation distribution in the loess plateau of China. Soil and Tillage Research 191, 66-74 (2019).

435. Yadav, G. S. et al. Soil carbon dynamics and productivity of rice-rice system under conservation tillage in submerged and unsubmerged ecologies of Eastern Indian Himalaya. Carbon Management 10, 51-62 (2019).

436. Yadav, G. S. et al. Impact of no-till and mulching on soil carbon sequestration under rice (Oryza sativa L.)-rapeseed (Brassica campestris L. var. rapeseed) cropping system in hilly agro-ecosystem of the Eastern Himalayas, India. Agriculture, Ecosystems \& Environment 275, 81-92 (2019).

437. Yadav, G. S. et al. Conservation tillage and mulching effects on the adaptive capacity of direct-seeded upland rice (Oryza sativa L.) to alleviate weed and moisture stresses in the North Eastern Himalayan Region of India. Archives of Agronomy and Soil Science 64, 1254-1267 (2018).

438. Yadav, G. S. et al. Conservation tillage and nutrient management effects on productivity and soil carbon sequestration under double cropping of rice in north eastern region of India. Ecological Indicators 105, 303-315 (2019).

439. Yadav, G. S. et al. Effect of No-Till and Raised-Bed Planting on Soil Moisture Conservation and Productivity of Summer Maize (Zea mays) in Eastern Himalayas. Agricultural Research 7, 300-310 (2018).

440. Yadvinder-Singh et al. Nitrogen and residue management effects on agronomic productivity and nitrogen use efficiency in ricewheat system in Indian Punjab. Nutrient Cycling in Agroecosystems 84, 141-154 (2009).

441. Yang, X. et al. Modelling the effects of conservation tillage on crop water productivity, soil water dynamics and evapotranspiration of a maize-winter wheat-soybean rotation system on the Loess Plateau of China using APSIM. Agricultural Systems 166, 111-123 (2018).

442. Yang, Y. et al. Effects of tillage and mulching measures on soil moisture and temperature, photosynthetic characteristics and yield of winter wheat. Agricultural Water Management 201, 299-308 (2018).

443. Yiridoe, E. K., Vyn, T. J., Weersink, A., Hooker, D. C. \& Swanton, C. Farm-level profitability analysis of alternative tillage systems on clay soils. Canadian Journal of Plant Science 80, 65-73 (2000).

444. Yoo, K. H., Touchton, J. T. \& Walker, R. H. Runoff, sediment and nutrient losses from various tillage systems of cotton. Soil and Tillage Research 12, 13-24 (1988). 
445. Zhang, X. et al. Tillage and residue management for long-term wheat-maize cropping in the North China Plain: I. Crop yield and integrated soil fertility index. Field Crops Research 221, 157-165 (2018).

446. Zhang, Y. et al. Soil water use and crop yield increase under different long-term fertilization practices incorporated with two-year tillage rotations. Agricultural Water Management 221, 362-370 (2019).

447. Zhang, Y. et al. The effects of rotating conservation tillage with conventional tillage on soil properties and grain yields in winter wheat-spring maize rotations. Agricultural and Forest Meteorology 263, 107-117 (2018).

448. Zhang, Y. et al. Crop yield and soil properties of dryland winter wheat-spring maize rotation in response to 10-year fertilization and conservation tillage practices on the Loess Plateau. Field Crops Research 225, 170-179 (2018).

449. Zhao, C. et al. No-tillage reduces competition and enhances compensatory growth of maize (Zea mays L.) intercropped with pea (Pisum sativum L.). Field Crops Research 243, 107611 (2019).

450. Žugec, I. The effect of reduced soil tillage on maize (Zea mays L.) grain yield in Eastern Crotia (Yugoslavia). Soil and Tillage Research 7, 19-28 (1986).

\section{Acknowledgements}

This work was supported by the ANR under the "Investissements d'avenir" program with the reference ANR-16CONV-0003 (CLAND) and by the INRAE CIRAD meta-program "GloFoods".

\section{Author contributions}

The three authors contributed equally to the project design and substantially review. Yang Su worked on the data collection, and all the authors worked together on data analysis and the drafting of the final version of the manuscript.

Competing interests

The authors declare no competing interests.

\section{Additional information}

Supplementary information The online version contains supplementary material available at https://doi. org/10.1038/s41597-021-00817-x.

Correspondence and requests for materials should be addressed to Y.S.

Reprints and permissions information is available at www.nature.com/reprints.

Publisher's note Springer Nature remains neutral with regard to jurisdictional claims in published maps and institutional affiliations.

(c) (i) Open Access This article is licensed under a Creative Commons Attribution 4.0 International License, which permits use, sharing, adaptation, distribution and reproduction in any medium or format, as long as you give appropriate credit to the original author(s) and the source, provide a link to the Creative Commons license, and indicate if changes were made. The images or other third party material in this article are included in the article's Creative Commons license, unless indicated otherwise in a credit line to the material. If material is not included in the article's Creative Commons license and your intended use is not permitted by statutory regulation or exceeds the permitted use, you will need to obtain permission directly from the copyright holder. To view a copy of this license, visit http://creativecommons.org/licenses/by/4.0/.

The Creative Commons Public Domain Dedication waiver http://creativecommons.org/publicdomain/zero/1.0/ applies to the metadata files associated with this article.

(c) The Author(s) 2021 